\title{
HOW WELL DO FOREIGN EXCHANGE \\ MARKETS FUNCTION: MIGHT A TOBIN TAX HELP?
}

Jeffrey A. Frankel

Working Paper 5422

\author{
NATIONAL BUREAU OF ECONOMIC RESEARCH \\ 1050 Massachusetts Avenue \\ Cambridge, MA 02138 \\ January 1996
}

This paper was written for a conference, "New and Innovative Sources of Financing Development," United Nations Development Programme, New York City, October 10, 1995. It is forthcoming in a volume from Oxford University Press, 1996. The author would like to thank Richard Lyons and the Harvard University international economics seminar for useful discussion, and to thank the Bank of England, the Bank of Japan, and the Federal Reserve Bank of New York, for making available the latest statistics. This paper is part of NBER's research program in International Finance and Macroeconomics. Any opinions expressed are those of the author and not those of the National Bureau of Economic Research.

(C) 1996 by Jeffrey A. Frankel. All rights reserved. Short sections of text, not to exceed two paragraphs, may be quoted without explicit permission provided that full credit, including $\odot$ notice, is given to the source. 


\title{
HOW WELL DO FOREIGN EXCHANGE \\ MARKETS FUNCTION: MIGHT A TOBIN TAX HELP?
}

\begin{abstract}
Figures for 1995 estimate trading by dealers in the foreign exchange market at over $\$ 1,200$ billion per day, most of it with other dealers. Some have linked this volume to concerns of excessive volatility in the market. Tobin's proposal to address this volatility with a small tax on all foreign exchange transactions has not received the serious attention it deserves. The paper argues that a better case can be made for the proposition that the tax might dampen exchange rate volatility than most economists believe. Calculations show that the tax, unlike some forms of capital control, would fall far more heavily on short-term transactions than long-term. Survey data and a simple model suggest, in turn, that short-term activity can be destabilizing. The paper also offers crude estimates of the revenue that would be raised from the Tobin tax. It is left to other authors to examine a major shortcoming of the proposal, enforceability.
\end{abstract}

Jeffrey A. Frankel

Department of Economics

549 Evans Hall

University of California

Berkeley, CA $94720-3880$

and NBER 


\section{How Well Do Foreign Exchange Markets Function: \\ Might a Tobin Tax Help?}

\section{Introduction:}

\section{How Well Do the Foreign Exchange Markets Function Currently?}

Many observers have concluded that the international monetary system is not working well, particularly the foreign exchange market. The conclusion is fed by some recent developments in international financial markets, on the one hand, and by a number of academic findings on the other. We begin the paper by noting in this part the concern with currency misalignments and crises. Subsequent parts of the paper will describe the numbers and mechanics of the foreign exchange market, and review academic findings that shed light on whether the market is functioning as it should, before turning to the question of reform.

\section{Misalignments, Overvaluations, and Crashes}

In the 1970s, the majority view among economists was that floating exchange rates were the right way to avoid undervaluations and overvaluations, such as the overvaluation to which the dollar had become increasingly subject in the 1960 s. The market usually knows better than governments what is the true value of the currency. Most economists had become persuaded by the argument that Milton Friedman made as far back as 1950: that speculators would on the whole be stabilizing rather than destabilizing, because any who increased the magnitude of exchange rate fluctuations could only do so by buying high and selling low, which is a recipe for going out of business pretty quickly. 
The pendulum began to swing back in the 1980s. The decade began with Mundell and a few supply-siders arguing for some version of a retum to the gold standard. Concerns about floating rates became much more widespread with the sharp appreciation of the dollar in the early 1980s, culminating in what some viewed as a dollar bubble in 1984-85. The market sometimes gets it wrong. (We may have seen another bubble more recently, with the appreciation of the yen in 1994 and early 1995). A variety of proposals appeared in the 1980s, to stabilize exchange rates among the major currencies. Some economists argue that going to a target zone or fixed rate would eliminate the speculative bubbles (e.g., John Williamson, 1985).

\section{Rational speculative bubbles}

The notion that financial markets might suffer from excessive volatility has been boosted by the theory of rational speculative bubbles. The initial motivation for the theory was purely as a mathematical curiosum. But the theory of speculative bubbles turned out to be a demonstration that speculators could be destabilizing without losing money. In a rational speculative bubble, the price goes up each period because traders expect it to go up further the next period, and in this expectation they are correct. Even though the price becomes increasingly far removed from the value justified by economic fundamentals, each individual trader knows that he or she would lose money if he or she tried to buck the trend on his own. These rational speculative bubbles are an effective answer to Milton Friedman's old point that destabilizing speculators would lose money.

The main problem with the theory of rational speculative bubbles is that it has nothing 
to say about what gets bubbles started (or what causes them to burst). Under the theory the exchange rate is simply indeterminate. The theory also offer no particular grounds for thinking that such destabilizing speculation would disappear with government action. Episodes such as the 1984-85 dollar and 1994-95 yen may be better understood by models with small deviations from rational expectations. Some models have two classes of actors: technical analysts or "noise traders" on the one hand, and the traditional fundamentalists (whose expectations would be rational, were it not for the existence of the noise traders) on the other hand. The result can be a speculative bubble developing on the back of a movement that originated in fundamentals. I call it overshooting of the overshooting equilibrium.

\section{Recent fixed-rate experiments, and the yearning for a "third way"}

A further reason that the pendulum swung partway from floating to fixed in the 1980 s was the emergence of the nominal anchor argument, especially for smaller countries. This is a prescription to peg exchange rates firmly, as a credible pre-commitment on the part of the monetary authorities not to inflate. This became a popular argument both for southern European countries joining the EMS, and for LDCs adopting stabilization programs based on fixing the exchange rate. This shift in sentiment was due in large part to the high inflation rates of the 1970s, and the high output costs of reversing them in the early 1980s. (Even the IMF re-thought its previous emphasis on devaluations as a standard part of country programs, and began to look favorably on exchange-rate based stabilization programs.)

In the last three years, the disenchantment with pure floating seems to have given way 
to a renewed disenchantment with fixing. The reason: a number of disruptive crises that have occurred where countries had tried to fix their rates. It is true that many of these exchange rate crises have been the result of governments trying to defend parities that are no longer justified by fundamentals. Prominent examples include the pound and lira in 1992, and Mexico in December 1994. (Among the many precursors were the UK crises of 1931, 1949 and 1967, the dollar crisis of 1973, and the Chilean collapse of 1982.) The mainstream economist's view is that these crises were the fault of the governments, not of the markets.

But unwarranted speculative attacks can happen under fixed rates or target zones too, e.g., the French franc in 1993. The theory has been supplied in so-called "secondgeneration" models of speculative attacks, which feature multiple equilibria. ${ }^{1}$ Judged by such macro fundamentals as inflation and interest rates, the franc was not overvalued against the mark in 1993, and yet was forced by speculative attack to abandon its $21 / 4 \%$ margins. These speculative attacks are the fixed-rate analog of the speculative bubbles that arise under floating rates. Concluding that unwarranted speculation seems to bedevil both floating rates and fixed rates, some observers have suggested a third way, along the lines of the tax on all foreign exchange transactions that was proposed by James Tobin in $1978 .^{2}$

${ }^{1}$ E.g., Obstfeld (1994). Also Flood and Garber, and others.

${ }^{2}$ E.g., Tobin (1992), and Eichengreen, Tobin and Wyplosz (1995). It should be noted, however, that the Tobin tax differs in a number of important specific ways from other "sand in the wheels" taxes or controls on international capital flows, such as the proposal of Eichengreen and Wyplosz, or the reserve requirements on capital inflows that have been adopted by Chile in the 1990s (e.g., Ffrench-Davis and Agosin, 1995). Table 1 sketches out the differences. 


\section{The Nature of Foreign Exchange Trading}

It is important to understand the market for currencies at a level of detail that is at least somewhat less abstract than the standard macroeconomic theories. The "foreign exchange market" is not a centralized location, but rather the sum total of transactions in which national currencies are traded for one another. We begin by considering the size, structure and composition of the market.

\section{The size of the market}

The most salient aspect of the foreign exchange market is its size. Our information comes from the surveys that are conducted every three years by major central banks, and aggregated by the Bank for International Settlements (BIS) in Basle. Figure 1 illustrates the growth in trading volume in the U.S. market over the last 15 years. Total volume increased more than four-fold from 1977 to 1980 [gross; not shown]. Volume corrected for doublecounting increased $44 \%$ between 1980 and 1983 . Trading roughly doubled between 1983 and 1986, and roughly doubled again between 1986 and 1989 (among the four major markets). It then increased by 42 per cent between 1989 and 1992 (globally). ${ }^{3}$ The survey of April 1992 produced a total figure (after eliminating double-counting) of $\$ 880$ billion of trading per day. This number, perhaps with an allowance for the growth in trading that had presumably taken place since 1992 , has often been cheerfully rounded off to a trillion dollars.

${ }^{3}$ Bank for International Settlements, 1993. 
We now have a much better idea of current trading volume. The April 1995 surveys have been conducted. As in the past, the Federal Reserve, Bank of Japan and Bank of England announced the results in their markets (the three largest) in September of 1995 . The subsequent BIS report on the total adjusts for double-counting across the largest markets, and adds in the other smaller markets as well, for a total of 26 countries.

The latest surveys show a 46 per cent increase in volume from April 1992 to April 1995 , to the level of $\$ 244$ billion a day, in New York; a 34.3 per cent increase, to the level of $\$ 161.4$ billion, in Tokyo; a 60 per cent increase, to the level of $\$ 464$ billion in London; a 43 per cent increase to the level of $\$ 105$ billion in Singapore; a 50 per cent increase to $\$ 90$ billion in Hong Kong; and a 32 per cent increase to $\$ 86$ billion in Switzerland. (These figures have been adjusted for double-counting within each market.) The simple total for the six markets is $\$ 1,152$ billion, a 48 per cent increase. The final BIS total for the larger set of central banks, adjusting for international double-counting, shows a new worldwide figure of $\$ 1,230$ billion a day (BIS, 1995).

The increases in trading volume would not look quite as large when measured in yen, marks, and other foreign currencies. The reason, of course, is that the dollar has depreciated against those currencies since 1992.

There had been a fear that trading may have been unrepresentatively low in the month of April 1992, and unrepresentatively high in April 1995. The former was a period of relatively low volatility in the foreign exchange market, and the latter a period of high volatility, particularly in the yen/dollar market, and trading volume is known to be correlated 
with volatility. ${ }^{4}$ If so, the rate of growth over the last three years is overstated. It turns out that in the 1995 New York survey only 7 per cent of the participants reported a view that trading activity in April was above normal that month, while 48 per cent reported a view that it was in fact below normal (Annex I). It is still likely that volume in Tokyo was unusually high.

\section{The structure of the market}

As noted, the market is decentralized. It is dealer-driven, over-the-counter, and nontransparent. The New York Stock Exchange, by contrast, is centralized. When a stock broker executes a trade on behalf of a client, the price and quantity are public information. Foreign exchange dealers are under no obligation to disclose this information; to the contrary, their ability to earn a living hinges on their skill at gleaning more information from other traders, particularly in the form of trades, than they reveal.

According to the 1992 survey, roughly 1 in 3 transactions were executed in the traditional way, by speaker phone (typically at prices with narrower spreads than the indicative prices quoted over computer screens). Roughly 1 in 3 were settled by automated dealer systems where no voice contact is necessary. Finally, as had long been true, about 1 in 3 were settled via brokers. Brokers simply match buy and sell orders from dealers, without taking a position themselves.

The 1995 survey reports that the split between direct inter-dealer trading and

${ }^{4}$ Frankel and Froot (1990), Hsieh and Kleidon (1994), and Jorion (1994). Judging by options prices, implied volatility in April was double the level of December-February. 
brokerage is similar to 1992: the brokers' share is 37 per cent now, vs. $35 \%$ then. The survey also reports a new phenomenon, the growth of automated brokerage (electronic order matching), as distinct from automated systems for direct trading, to 13 per cent of the total market volume, from virtually nothing in 1992. (The two automated brokerage systems operating in the United States are EBS -- Electronic Brokerage System -- and Reuters

Dealing 2000-2. The older automated trading system is Reuters Dealing 2000-1.5) Figure 2 illustrates the decomposition by trading method. The brokerage share was similarly steadily in London, at 35 per cent.

The number of firms that trade a given currency in a given market is relatively small. Nevertheless, the survey suggests that the foreign exchange market is highly competitive (p.8). Among the top ten dealers, only four dealers' rankings remained unchanged between 1992 and 1995, and three of the top ten were not among the top ten in 1992. Among the top ten dealers in either 1992 or 1995 , four saw their ranking fall by five places or more, while four saw their ranking rise by five places or more. Moreover, there was a gain in the market share of the second tier of dealers in the top twenty firms. The Bank of England survey reports similar statistics (p.6). It should be noted that some of this shuffling of firms' rankings may be due to individual traders switching employers. ${ }^{6}$

These indicators of competition say little about whether the brokers or Reuters feel

5 A set of Reuters 2000-1 data is analyzed by Lyons (1993, 1994, 1995a). A set of Reuters 2000-2 data is analyzed by Goodhart, Ito and Payne (1995). (See the comment by Lyons, 1995b.)

- The New York survey covered 130 foreign exchange dealers active in the United States (Annex I). Average deal size was $\$ 15$ million per trade (p.11), though most spot trades are smaller. 
free to compete with the dealers by offering an alternative market altogether, in which customers could trade directly. The distinction is competition within a market versus competition between market structures.

\section{The composition of the market}

The surveys decompose total trading along a number of dimensions: location, currency, type of contract, and counter-party.

\section{a. Location}

London has long been the largest market. The latest survey now shows that London is larger than New York and Tokyo combined, as the Sept. 20, 1995, Financial Times trumpeted. Growth in the Japanese market, which was very rapid in the early 1980 s as the result of liberalization, has slowed down sharply. It is Singapore and Hong Kong, instead, that have gained rapidly in the East Asian time zone. The relative shares for April 1995 garnered by the four largest markets are: .476 London, .250 New York, .166 Tokyo, and .108 Singapore. Singapore gained the number four slot in 1992, but Hong Kong and Switzerland are close behind.

The list of 26 central banks reporting to the BIS includes such small "offshore" countries as Bahrain and Luxembourg. It does not include such "off- offshore" centers as the Cayman Islands or the Isle of Man, which are ready to provide a comfortable home for currency traders should the established centers become less hospitable. 


\section{b. Currency composition}

The shares of currencies in foreign exchange trading add up to 200 per cent, since each trade involves two currencies. Until relatively recently, the dollar was used in almost 99 per cent of trades, serving as the "vehicle currency" when customers wanted to go from one lesser currency to another. The dollar's share has declined, however. According to the 1995 survey of the U.S. market, the dollar appeared in 86 per cent of trades. (13 per cent featured the DM against third currencies, and less than one per cent featured third currencies against each other.) The total share of the DM was 43 per cent (of which about 29 per cent is against the dollar). In third place was the yen, with 23 per cent, followed by pound sterling, Swiss francs, and French francs. A tremendous increase in French franc trading is attributed to the aftermath of the 1992 and 1993 crises in the European Exchange Rate Mechanism. (Figure 3.)

According to the Bank of Japan, the U.S. dollar share in Tokyo trading in 1995 remained high at 93.7 per cent, followed by the yen at 81.1 per cent, and the mark at a distant 15.4 per cent. As the London market is by far the biggest, its currency composition figures prominently in the worldwide total. The aggregation of 21 financial centers in the 1992 data showed pound sterling in the number four position, followed by the Swiss franc, French franc, Canadian dollar, and ECU.

\section{c. Spot vs. forward composition}

The decomposition by foreign exchange products is little changed in 1995 from earlier surveys, though a gradual downward trend in the share of spot transactions has continued. 
New York turnover volume was 55 per cent in spot transactions. The rest can be broadly described as forward transactions ( 34 per cent swaps and 11 per cent actual forward contracts). The trend within the brokered portion of these market segments is the reverse of the trend in the overall market: the share of spot transactions rose sharply, as part of the rise of automated brokerage systems (which as yet broker only spot transactions). Japan interbank volume was 36.4 per cent in spot and 63.6 per cent in forwards and swaps. In Tokyo the (smaller) volume of customer transactions is 28.7 per cent in spot and 71.3 in forwards in swaps. In London, forward transactions rose to 59 per cent of total transactions in 1995 , versus 41 per cent in spot.

\section{d. Customer composition}

Perhaps the most striking aspect of the foreign exchange market, after its total volume, has long been the low percentage of trades on behalf of ultimate customers. Ultimate customers are those like exporters, or issuers of international bonds, who wish to sell foreign exchange, or those like importers, or international investors, who wish to buy foreign exchange. A much-cited figure of $5 \%$ transactions with non-financial customers, versus $95 \%$ with other dealers, comes from earlier surveys. In the 1992 survey, the figure had increased to $12 \%$ ?

Still, this says that each dollar of foreign exchange that is cashed in by a customer is passed around about eight times among dealers, like a "hot potato," until it finds someone

${ }^{7}$ In London, "...the proportion of business with non-financial customers and other financial institutions has risen to 23\% of daily turnover." [Bank of England, 1992, p.408.] 
willing to hold it. One interpretation is that these traders are buying and selling based on frequently-changing and differently-perceived news regarding monetary fundamentals or other information relevant for determining the value of the currency. The alternative is that it is for some reason cheaper for each dealer to pass the foreign exchange on to the next dealer whom he happens to encounter and who is even marginally more willing to hold the currency, than it is, for example, to auction it off in order to try to find the one trader who most wants to hold it. ${ }^{8}$

In the 1995 surveys, the percentage of New York trading volume with non-financial customers has grown another three percentage points (to $17 \%$, from $14 \%$ in 1992). The percentage of volume with financial customers is $27 \%$ (Figure 4). The percentage of Tokyo trading volume with all customers (financial and non-financial, i.e., all non-banks) is $26.5 \%$ (having fallen slightly, from $26.8 \%$ in 1992 and $30.3 \%$ in 1989). In London, the share with financial customers continued a steady upward trend, to 18 per cent, and the share with nonfinancial customers was fairly steady at 7 per cent. The three markets together imply an aggregate customer-to-transaction ratio of .306 . The London and New York statistics imply a ratio for nonfinancial customers of .18. (The Bank of Japan does not offer this latter breakdown.)

The U.S. survey (p.9) reports that the volume of trade grew most rapidly with financial customers (100 per cent growth), as compared to non-financial customers (78\% growth) and interdealer trading (22\% growth). It seems likely that the rapid growth in trade

8 The hot potato interpretation is supported empirically in a study of the actual second-by-second behavior of an individual trader: Lyons $(1994,1995)$. 
with financial customers reflects in large part the increased participation of hedge funds, corporate treasurers and other institutions (e.g., the universally-cited George Soros). ${ }^{9}$ The 1993 International Monetary Fund Capital Markets Report described the growing importance of such players in the market (the corporate treasurers in fact reported to be more important than the Soroses). It is likely that such customers would respond more to an increase in transactions costs such as a Tobin tax than would traditional customers such as importers and exporters. This is worth keeping in mind when we come to discuss the likely effect on the volume of transactions.

\section{Academic Findings to Assess Whether the Market Works Well}

\section{Is Exchange Rate Volatility Excessive?}

Everyone describes floating exchange rates as highly volatile. But volatile compared to what? They are more volatile than they were expected to be before the 1973 move to floating rates, more volatile than the prices of goods and services, and more volatile than apparent monetary fundamentals. This is not the same, however, as saying that they are excessively volatile. Even if foreign exchange markets are functioning properly, fundamental economic determinants, such as monetary policy, should produce a lot of variability in the exchange rate. Dornbusch's famous "overshooting theory" of exchange rate determination, for example, predicts that a relatively small increase in the money supply will cause a

${ }^{9}$ Hedge funds manage portfolios for a small number of relatively large individual investors. They deal heavily in derivatives, but the implication of the name is the reverse of the truth: they speculate rather than hedge. 
relatively large increase in the price of foreign exchange. (The foreign currency will appreciate so much that it is generally perceived as "overvalued," in the sense that it is expected to depreciate gradually in the future, at a speed that is just sufficient to compensate investors for the fact that domestic assets pay a lower interest rate.) The important questions are whether volatility is higher than necessary, and what the harmful effects might be.

\section{Evidence of adverse effects from short-term volatility}

The concern about exchange rate volatility has always been possible adverse effects on trade and investment. Here the academic attack has been muted, large swings or "misalignments" receiving more concern from economists. Most studies have concluded that there is little effect of short-term volatility on trade. ${ }^{10}$ But the belief in an adverse effect has nevertheless been a major motivation behind attempts to link European currencies, via the ERM, and now via EMU.

A study of bilateral trade shows statistically significant effects of bilateral volatility in the 1960s and 1970s. When estimated by Ordinary Least Squares, the effect in 1980 on trade of adopting fixed exchange rates worldwide was large: $+22 \%(=6.97 * 3.22 \%){ }^{11}$ One must immediately add three major qualifications, however: (1) The estimated effect disappears in the 1980s. Quite possibly the spreading use of futures, options, and other instruments means that firms learned in the 1980s how to hedge currency risk effectively. (2) There is certainly a simultaneity problem in the OLS estimates: one cannot tell from the

\footnotetext{
${ }^{10}$ The evidence has recently been reviewed by Goldstein (1995).

"Frankel and Wei (1995).
} 
correlation whether stabilizing bilateral exchange rate variability promotes bilateral trade, or strong trade links lead to the decision to stabilize exchange rates vis-a-vis particular trade partners. An allowance for this simultaneity produces an estimated volatility effect that, while significant up to 1980 , is far smaller in magnitude. (3) The observed exchange rate variability could be inevitable real risk, which would pop up elsewhere if suppressed in the foreign exchange market. But, there is evidence relevant to this last point.

\section{If volatility were suppressed in the foreign exchange market, would it show up elsewhere?}

Econometric research has failed to explain most exchange rate movements by fundamentals (especially on a short-term basis). ${ }^{12}$ Logically, this failure leaves two possible explanations: (1) unobservable fundamentals, or (2) bubbles (defined as exchange rate movements not based on fundamentals). In the first case, we would still be subject to the standard presumption of neoclassical economics that if volatility were somehow suppressed in the foreign exchange market, it would simply show up elsewhere. Imagine, for example, that the fundamental origin of the appreciation of the dollar in the first half of the 1980 s were an increase in worldwide demand for U.S. goods, and therefore an increase in demand for U.S. currency to buy those goods (a real appreciation). An attempt on the part of the U.S. monetary authorities to suppress the appreciation would consist of purchases of foreign currencies, putting more dollars in the hands of the public. This increase in the U.S. money

${ }^{12}$ E.g., Meese and Rogoff (1983) and Campbell and Clarida (1987). A recent survey of the empirical literature on exchange rate determination is Frankel and Rose (1995). 
supply would have been inflationary. The increase in U.S. relative prices (the real appreciation) would have occurred anyway, but it would simply have taken the undesirable form of inflation. Can we judge that exchange rate movements are due to unobservable fundamentals, rather than bubbles?

\section{Evidence from fixed vs. floating regimes}

Arguing against the unobservable fundamentals explanation is the pattern whereby nominal and real exchange rate variability has increased whenever there is a shift from a fixed to a floating regime. Figure 5 offers an illustration. ${ }^{13}$ Furthermore, there is no reduction in variability of fundamentals to keep the exchnage rate in line, when moving from floating rate regimes to fixed rate regimes. ${ }^{14}$ This seems to leave speculative bubbles as the remaining explanation for much of the short-term variation in exchange rates. If this conclusion is correct, it would likely follow that exchange rates are unnecessarily volatile.

\section{Are forecasters biased and markets inefficient?}

There is a widely-documented apparent bias in expectations, e.g., as reflected in the forward exchange market. The forward discount actually points the wrong way as a predictor of the exchange rate. The bias is usually interpreted simply as an exchange risk premium, (1988).

13 The example of Ireland is a particularly convincing demonstration, in Mussa

14 E.g., Flood and Rose (1993). 
but there is some evidence against this view. ${ }^{15}$ It is possible that the bias is evidence of market inefficiency.

\section{Is speculation destabilizing?}

There is also apparent evidence in survey data of extrapolation on the part of market participants, in forecasts at short horizons of under three months. If traders act based on such extrapolative expectations, they will create bandwagons: an upward blip will generate expectations of future appreciation, leading to buy orders, and thereby contributing to the upward trend. Unless the survey data are misleading us, there seems to be evidence of destabilizing speculation. ${ }^{16}$

At longer horizons of three months to one year, however, forecasts seem to fit better the patterns of adaptive, regressive, or distributed lag expectations. All three mechanisms of expectations formation, if acted upon by traders, would lead to stabilizing speculation. ${ }^{17}$

Table 2 summarizes the key results from the survey studies (from Frankel, 1993, p.324). The estimated extrapolative parameter is relatively high at the one week horizon. A one percent appreciation in a given week generates on average an expectation of .13 per cent further appreciation over the coming week. The extrapolative parameter is lower at the 4week horizon. It changes sign at the 3-month horizon: a one per cent appreciation generates an expectation of .08 per cent depreciation over the coming three months. This tendency to

${ }^{15}$ E.g., Froot and Frankel (1989), and other chapters in Frankel (1993). Engel (1995) has recently surveyed the subject.

${ }^{16}$ Frankel and Froot (1987b, 1990a), Froot and Ito (1989) and Ito (1994).

${ }^{17}$ Frankel and Froot (1987). 
expect a reversal continues to get stronger with longer horizons. The one per cent appreciation generates an expectation of .33 per cent depreciation over the coming 12 months.

Which horizon dominates actual foreign currency trading? The horizon at which most trading takes place is actually shorter than one day. Traders at most banks take large positions for a few hours, but limit their overnight and weekend positions sharply, or close them out altogether. ${ }^{18}$ This does not in itself necessarily mean that the determination of the market price is dominated by short horizons. If traders are fully rational, even though they trade at short horizons, their expectation of how much a currency will be worth one period from now will be tied down by their rational forecast of how much it will be worth one year from now. The question is whether this tying of the short-term to the long-term is in fact operative. The survey data results summarized in Table 2 seem to suggest that short-term expectations are not in fact formed by looking far into the future. Given the high level of volatility, the one-hour share of a rationally expected year-long return to fundamentals equilibrium is a very minor factor in the traders' calculation on each trade. ${ }^{19}$

\section{7. "Overshooting the overshooting equilibrium"}

Effects of exogenous changes in monetary policy are apparently not instantaneous, as

\section{Fieleke (1981).}

${ }^{19}$ The short horizon of most foreign exchange trading is documented in many places, including in Frankel (1993). 
they should be in theory, but rather are drawn out over time. ${ }^{20}$ This could be an example of how speculative bubbles get started.

A number of researchers have deviated from the rational expectations paradigm to sketch what might be called theories of endogenous speculative bubbles. They typically start from the proposition that market participants' forecasts are drawn from competing views, including for example both technical analysis and economic fundamentals. From there they attempt to build models of exchange rate determination. Relevant studies include Goodhart (1988), Frankel and Froot (1986, 1990a), Cutler, Poterba and Summers (1991), De Long, Shleifer, Summers and Waldmann (1990) and Goldberg and Frydman (1993). In such models, changes in the weights assigned by the market to the competing models can themselves alter asset demands and give rise to changes in the exchange rate. DeGrauwe and Dewachter (1990) show that the interaction of chartists and fundamentalists can give rise to an exchange rate process characterized by chaos: a process that is essentially unpredictable, despite the fact that the underlying model is deterministic. Krugman and Miller (1993) shouw the role of stop-loss order traders.

If it takes a year, for example, for the full effects of a monetary tightening to be felt in the exchange rate, then during most of that year those who forecast by extrapolating (the technical analysts or chartists) have had a good track record. Observing this, traders switch from fundamentalist forecasting techniques to technical analysis, thereby increasing the demand for the appreciating currency, and prolonging the appreciation, even after the

${ }^{20}$ Eichenbaum and Evans (1995). 
fundamentals may have turned around (as they had for the dollar by July 1984 and probably had for the yen by February 1994). This is what I mean by overshooting the overshooting equilibrium. It is capable of explaining some of the other puzzling findings, such as the tendency of the currency to move up in the future when the forward discount or interest differential points down: In the aftermath of an increase in the interest rate differential, the currency appreciates over the subsequent year, rather then appreciating instantaneously and then depreciating gradually as it should in the efficient-markets overshooting theory.

\section{What is the Case for a Tobin Tax in the Foreign Exchange Market?}

An interesting aspect of the proposal to tax international financial transactions is that it has three quite distinct justifications, and many proponents emphasize one or two of them to the exclusion of the others. The motivations are: international monetary reform, shifting resources away from the financial sector (particularly away from speculators), and raising

revenue for new projects. International economists think of the proposal as one motivated by a desire to reform international currency markets, particularly to reduce exchange rate volatility. Those countries that have already tried securities transactions taxes -- which have levied them on trading in stocks and bonds, not foreign exchange transactions -- have been motivated primarily by a desire to scoop up what is popularly seen as excessive compensation accruing to financial traders. Reducing market volatility is mentioned 
surprisingly seldom. ${ }^{21}$ Finally, many proponents of a Tobin tax, particularly those who have revived the idea in the 1990s, are motivated explicitly by a desire to fund worthy international ventures. Najman and d'Orville, for example, explicitly recommend against relying on the first or second justifications. They present the Tobin tax as one of the more promising on a list of possible ways of financing needed international projects. The financial sector is not deliberately targeted, beyond the observation that taxing international activities has more legitimacy for such purposes than taxing domestic activities.

\section{Might a Tobin Tax Reduce Speculative Activity?}

The question for economists is: How could a Tobin tax discourage undesirable destabilizing speculation, without at the same time discouraging desirable investment?

\section{a. Large disincentive to short-term transactions under floating}

As a number of authors have demonstrated, the Tobin tax would penalize short-term transactions far more than long-term transactions. ${ }^{22}$ Suppose the rate of return at home is $i$ per cent per year. The required rate of return abroad (including tax evasion and exchange gains) $i^{*}$ depends on the Tobin tax, $t$, and on the duration of the investment $y$, measured as the number of years, or fraction of years, for which a foreign position is held. As a first

${ }^{21}$ Campbell and Froot (1995) relate the experience in Sweden and the United Kingdom. Turnover taxes have also been used in recent years in Germany, Switzerland, Japan, and a majority of OECD countries. Even the United States has a nominal SEC fee ( $\$ .01$ assessed on sales per $\$ 300$ of value; Hakkio, 1994, p.19). The tax rates for many countries are reported in Table 3, borrowed from Campbell and Froot.

${ }^{22}$ This version is drawn from Dombusch and Frankel (1988). 
example, consider a round-trip investment. Those seeking to invest abroad must pay the tax twice, once when the foreign asset is bought and again when it is sold. For returns to be equalized on domestic investments and foreign investments, we must have:

$$
\left(1+i^{*} y\right)(1-t)-t=1+i y .
$$

Solving for the required rate of return abroad,

$$
\begin{aligned}
i^{*} & =(i y+2 t) / y(1-t) . \\
& =(i+2 t / y) /(1-t) .
\end{aligned}
$$

As a second example, assume that only the interest earnings are brought back, and the principal is left in foreign currency. Those seeking to invest abroad must still pay the tax twice, once when the foreign asset is bought and again when the interest earnings are repatriated. For retums to be equalized on domestic investments and foreign investments, we must have:

$$
i^{*} y(1-t)-t=i y .
$$

Solving for the required rate of return abroad,

$$
\begin{aligned}
i^{*} & =(i y+t) / y(1-t) . \\
& =(i+t / y) /(1-t) .
\end{aligned}
$$

It is apparent that the Tobin tax penalizes short-term investments more the shorter is the horizon. For example, with a home interest rate of 10 per cent, a 1 per cent tax, and a 12-month investment horizon, the foreign yield would have to be at least 11 per cent $(=.11 / .99)$ to attract the investor. If the horizon were one month $(1 / 12$ of a year $)$, the foreign yield would have to rise to 22 per cent per annum to remain attractive. If the horizon were only one week (1/52 of a year), the foreign yield would have to be 62 per cent 
per annum!

\section{b. How discouraging short-term speculation might reduce volatility}

The Appendix to this paper presents a model that constitutes an attempt, albeit a very simple one, to appraise in a macroeconomic model the claim that the Tobin tax would reduce exchange rate volatility. The point is often made that there is no way of discouraging destabilizing speculation without at the same time discouraging international capital flows that are desirable for all sorts of other reasons (stabilizing speculation, risk-sharing, intertemporal consumption-smoothing, etc.). But it is possible to put a positive interpretation on the Tobin tax in particular. ${ }^{23}$

We have seen in the previous section that a small tax in proportion to the size of the foreign exchange purchase will not be much of a deterrent to anyone contemplating the purchase of a foreign security for longer-term investing. But it will discourage the spot trader who is now accustomed to buying foreign exchange with the intention of selling it a few hours later. Let us apply the more modest tax rate of .001 to the previous example. At a 12-month investment horizon, the foreign yield would have to be at least 10.1 per cent to compete with a 10.0 per cent interest rate at home. If the horizon were as short as one day, as it is for most traders, the foreign yield would have to rise to 46.5 per cent to remain attractive. At such short horizons, all but the boldest speculators would be driven out pretty quickly.

Frankel and Froot $(1986,1990 a, b)$ reported that "technical analysis" became

${ }^{23}$ This line of argument was developed in Frankel (1988, pp. 177-188). 
increasingly prevalent in the exchange rate forecasting business during the first half of the 1980s. Similarly, Taylor and Allen (1992) conducted a questionnaire survey on the use of technical analysis in the London foreign exchange in 1988. At least 90 per cent of respondents reported placing some weight on technical analysis, with the proportion rising steadily with the shortness of the horizon. These short-horizon technical analysts bear a striking resemblance to the infamous destabilizing speculators of classical financial mythology. Most of the rules of technical analysis seem to fit into the category of destabilizing behavior, such as the "momentum" models that call for buying when the current price exceeds the price that held, for example, five days ago.

If the destabilizing speculators in the Appendix model are indeed the short-term forecasters that the expectations survey data analyzed in Table 2 suggest, and the stabilizing speculators are the long-term investors, then the tax may indeed reduce the variance of the exchange rate. In terms of the model in the Appendix, it will reduce $f_{s}$ without having much effect on $f_{i}$. The turnover tax in this light is crucially different from other capital controls, such as the taxes on international interest earnings that were levied before 1973, by the United States to discourage capital outflow or Germany to discourage capital inflow. Such taxes reduced the rate of return to long-term investing just as much as the rate of return to short-term speculation (perhaps more, if one considers that capital gains were taxed at a lower rate than interest earnings).

\section{Might a Tobin Tax Restore Some Independence to National Monetary Policies?}

A corollary of the statement that a Tobin tax might reduce the volatility of exchange 
rates for any given movements in economic fundamentals, is the proposition that it might allow larger movements in fundamentals for any given exchange rate path. In other words, for countries seeking to maintain exchange rate stability, it might restore some measure of monetary policy independence. The question could be broken into three parts. 1. To what extent is independence desirable? 2. How much independence has been lost? And 3. Would a small Tobin tax help restore independence?

Clearly for countries that seek to stabilize their exchange rates, such as the members of the European countries that have been members of the Exchange Rate Mechanism and are putative candidates for European Monetary Union, a lot of independence has been lost. For many of them some measure of independence is desirable. Hence the conflict that forced Italy and the United Kingdom out of the ERM in 1992. This is the famous "Impossible Trinity": a country can have any two attributes out of financial openness, currency stability, and monetary independence, but it cannot have all three. The key question then becomes whether a sacrifice of financial integration as minor as a small Tobin tax would be sufficient to restore the other two legs of the trinity. I am skeptical. The speculators who successfully pushed against the limits of the ERM in September 1992 and August 1993 were seeking (successfully, as it turned out) returns well in excess of the 47 per cent annual rate that a small Tobin tax would counteract. The same is true of the large inflows and outflows such as Mexico underwent, respectively, in 1990-93 and 1994. Monetary independence will continue to be a privilege of those willing to live with large movements in their exchange rates. 


\section{Proceeds from the Tax}

A major motivation for the tax is clearly the large amount of revenue that it would generate.

\section{a. Projections of revenue}

Some wishful estimates of the amount of revenue that could be raised have simply multiplied the proposed tax rate times the volume of foreign exchange trading reported in the 1992 BIS survey, obtaining numbers as high as $\$ 10$ billion a day for a worldwide one per cent tax (or even $\$ 3,650$ billion a year, if the figure is incorrectly annualized by multiplying by 365 days). Tobin himself has suggested a figure of $\$ 1,500$ billion a year, to be raised from a worldwide tax of 0.5 per cent. ${ }^{24}$

Najman and d'Orville (1995) estimate the amount of revenue that could be raised by a tax on foreign exchange transactions, as of 1992 , at some $\$ 140.1$ billion for a tax of $0.25 \%$, or $\$ 56.32$ billion for a $0.1 \%$ tax..$^{25}$ This study -- which is otherwise relatively careful in many respects -- appears to have made a major mistake in calculating the amount of revenue. The authors appear to have assumed, incorrectly, that only that portion of transactions carried out via foreign exchange brokers would be subject to the tax, about one third of the

${ }^{24}$ Others have adopted this figure, or have associated simple multiples of it with corresponding multiples of the $0.5 \%$ tax. U.N.D.P. Human Development Report 1994, pages 7 and 69; as cited in Najman an d'Orville (1995, p.34).

${ }^{25}$ They propose applying a uniform $0.1 \%$ tax on government securities, Eurobonds and derivatives as well as foreign exchange, for a total estimated revenue of $\$ 120$ billion, plus an unestimated amount for a similar tax on corporate stocks and bonds. 
total. ${ }^{26}$ The mistake probably arose from assuming that the term "brokers" applies to all foreign exchange dealers or traders. In reality, the other $2 / 3$ of transactions are handled directly by foreign exchange dealers at private banks, who would be every bit as much subject to a Tobin tax as the brokers. (Dealers are defined as market-makers, who are willing both to buy and sell all the time. ${ }^{27}$ Brokers, again, are simply those who match buy and sell orders without taking a position themselves. If a tax were applied to them and not to other dealers, the only effect most likely would be to eliminate the brokers, without raising any revenue.) Indeed, given the increasing use of automated dealer systems in interdealer trading, one might argue that a tax would be more easily applied to this segment of trading than to the transactions that pass through brokers.

Thus the proper basis should have been something close to the full $\$ 880$ billion of daily turnover from the 1992 survey, multiplied by 240 trading days $=\$ 211$ trillion per year. While this basis is triple that used by Najman and d'Orville, an offsetting correction

26 "Some two-thirds of the turnover was generated by central banks and other actors (e.g., governments and official international organizations) which would be tax-exempt" (p.31). "As brokers handled, on average, 33\% of the tumover..., their 1992 turnover was some US\$ 70.4 trillion. In the absence of regular data, this adjusted figure should serve as the basis for developing recommendations as to the level of a transaction charge and calculating its notional yield..." (p.32). In reality, the official share of transactions, whether liable to tax or not, is much smaller than $2 / 3$. A gross upper bound on the share of official authorities is $1.3 \%$ in April 1989 (the figure also includes turnover in exchange-traded options and futures) and 8.6\% in April 1992 (this figure includes transactions with other nonreporting financial institutions). (BIS, 1993, p.12.) The "basis" that the authors have in mind should be the entire $\$ 880$ billion of daily turnover in April 1992 (\$211 trillion annualized), not just $1 / 3$ of that. Of course the basis then has to be reduced to reflect the response to a tax.

${ }^{27}$ Market participants themselves often apply the term "traders" to dealers. We will stick with the latter term in order to avoid confusion with traders like George Soros, who are financial customers. 
arises from the allowance for reduction in trading volume in response to the tax. They reduce volume by 20 per cent, leaving the tax base at $80 \%$ of its pre-tax level, which they regard as conservative. That their reduction is invariant with respect to the size of the tax -the same 20 per cent for a charge of $1.0 \%$ as for a charge of $0.05 \%$-- suggests that something is wrong. A more standard assumption for the responsiveness of the supply of a service, in this case foreign exchange trading, in response to a tax, would be a constant elasticity. A typical transaction cost for foreign exchange might be 0.1 per cent. (This is a generous estimate, applicable for a trade between a bank and a corporate customer. The actual number is likely to be much smaller for inter-dealer trading, which is the majority of trading currently.) So a charge of $0.1 \%$ would constitute at least a doubling of the current transaction cost. If such a tax reduces trading volume by 20 per cent, then the elasticity is about $0.32 .{ }^{28}$ If this same elasticity held for a tax of 1 per cent, so that the transaction cost were going up by a factor of 10 instead of a factor of 2 , then the drop in trading volume would be about 5 times as large as that suggested by the two authors, and the downward effect on tax revenue would be proportionate.

Of course the 20 per cent figure is arbitrary, as would be a decision to associate it with the $0.1 \%$ tax rather than a higher tax. Another consideration must be factored in. Most authors realize that any attempt to impose a non-negligible tax in one country alone, or even in all major industrialized countries, would result in much of the foreign exchange trading moving offshore. For that reason, the assumption is that the tax would be imposed

${ }^{28} \log (0.8) / \log (2.0)=-.322$. 
by "all" countries. The 20 per cent reduction in volume is meant to capture diversion to non-cooperating offshore centers and evasion, e.g., transactions among corporate affiliates, in the street, or disguised as derivative contracts, as well as a reduction in true trading volume. But there is reason to think that true trading volume would decline by more than this amount.

The decline in trading volume could be greater particularly if the decentralized dealer system were to collapse as a result of the tax, and give way to a centralized structure. As noted in Part I, the current structure of the foreign exchange market is a decentralized one, in which each dollar of foreign exchange that is cashed in by an exporter or other customer is passed around many times among dealers, like a "hot potato," until it finds someone willing to hold it for more than just a few hours. One can debate whether this structure is efficient. But it probably would not have evolved if transactions costs were not as razor-thin as they are. Indeed, the fall in transactions costs must be one major reason for the oft-noted increase in trading volume (a factor of fifty times in the United States alone, between 1977 and 1995). ${ }^{29}$ It is possible that the imposition of a Tobin tax, especially one as large as 0.5 $\%$ or $1.0 \%$ as has often been proposed, would alter the structure of the market in a fundamental way. It might become more like other major financial markets, where a sale or purchase by a customer generates only one or two transactions, rather than five or eight as seems to be the case in the surveys. This would particularly be the case if such a tax triggered a transition to a new trading structure equilibrium, with the decentralized dealer

29 The average bid-ask spread in DM in New York was twice as large in 1971, at 0.11 per cent, as in the late 1980 s, according to Froot (1990). 
network currency replaced by a system where foreign currency was traded on a centralized exchange in the manner of the NYSE. If the ratio of transactions to customer orders had fallen from eight to two, for example, the 1992 base would have fallen from $\$ 211$ trillion a year to $\$ 53$ trillion. A $1 \%$ tax would have raised "only" $\$ 530$ billion a year. That is still a lot of money.

To update the figures to April 1995, the most recent estimate of worldwide volume, $\$ 1,230$ billion per day, is $\$ 295.2$ trillion per year (240 trading days). The New York and London figures shows about 18 per cent of trades involving non-financial customers. If the ratio of total trades to trades with nonfinancial customers were to fall from 5-to-1 to 2-to-1, that would be a sixty per cent reduction in annual trading volume, from $\$ 295.2$ trillion to $\$ 118.1$ trillion. A $1 \%$ tax would thus raise $\$ 1.181$ trillion.

All of the foregoing calculations assume no change in the volume of customer transactions. In reality, the volume of orders from customers would change if the cost to them changed. I see no necessary reason for a decline in orders from exporters and importers. ${ }^{30}$ It seems reasonable to leave the non-financial customers' transactions alone, although one should be aware that even that segment of trading is far larger than the exports and imports that show up in the balance of payments. ${ }^{31}$

${ }^{30}$ If the cost of hedging foreign exchange risk is considered a material disincentive to importers and exporters, then a 1 per cent tax would also have a negative effect on trade. On the other hand, if it succeeded in reducing exchange rate risk, there might be an offsetting positive effect. For the speculative financial customers, a decrease in volatility might, if anything, have a negative effect on trading activity rather than a positive effect.

${ }^{31}$ Dollar trading is roughly 200 times the sum of the gross credits and debits in the U.S. balance of payments under trade, investment income, and capital flows. The role of the dollar in other countries explains some of this difference, but still leaves a large ratio. Total 
Many of the customer transactions are financial in nature. The hedge funds and other institutional investors would presumably trade less if the cost of trading went up. Campbell and Froot (1994) review several authors' estimates of sensitivity of securities trading volume in Sweden and the United Kingdom with respect to changes in transaction taxes. The estimates vary from 0.85 to 1.7 . These effects include the migration of trading offshore, which would be less relevant for a Tobin tax that was adopted in all countries.

The estimate of the revenue effect can be refined a bit. An elasticity of 0.32 for transactions initiated by financial customers might not be a bad guess. As already noted, such an elasticity would imply that a doubling of transaction costs to financial customers would reduce their trading volume by 20 per cent. As financial customers have been counted at 41 per cent of total customer transactions in New York and London combined, the implication is that customers in the aggregate would decide to make transactions 8 per cent less frequently $\left[.08=.41^{*} .20\right]$, from the currently estimate worldwide total of $\$ 376$ billion/day $[=.306 * \$ 1,230]$, to $\$ 346$ billion/day $[=.92 * 376]$. This would exacerbate the fall in total trading volume suggested above.

If the dealer-intermediated system were to disappear altogether, would the total trading volume fall to this level of $\$ 346$ billion? No, it would fall to half this level, or $\$ 173$ billion/day, because each trade would involve two customers transacting directly with each other, where it now involves only one. ${ }^{32}$ The 0.1 per cent tax, if it were big enough to

foreign exchange trading is approximately 100 times total world trade in goods and services.

${ }^{32}$ In other words, the total number of transactions per customer transactions would fall by a factor of about six. We are assuming here that there is no change in the frequency with which a vehicle currency (usually the dollar) is used. If the vehicle currency system 
change the structure of trading in this way, would then raise only $\$ 42$ billion in yearly revenue $[=.001 * 240$ days $* 173]$. Admittedly this outcome is unlikely. A tax as low as 0.1 per cent would not be sufficient to collapse the structure of trading and eliminate dealerintermediation from the system. If we assume that the customer-to-transaction ratio merely rises from the current .31 to .5 , the new transactions volume would be $\$ 693$ billion/day $[=346 / .5]$. Revenue would be $\$ 166$ billion per year [ $=.001 * 240$ days $* 693]$.

What if a higher tax rate of 1 per cent were enough to eliminate dealer intermediation? As in an earlier calculation, based on an elasticity of .32 (footnote 28), let us guess that increasing transactions costs by a factor of 10 would reduce financial customer transactions by half. Then total customer desire to trade would fall by 20 per cent $\left[=.41^{*} .5\right]$ to $\$ 301$ billion/day $[=.8 * 376]$, and total two-party transactions to half that, or $\$ 151$ billion/day, and yearly revenue to $\$ 361$ billion. ${ }^{33}$ Of course, all these estimates must be regarded as both preliminary and rough.

\section{b. Uses}

In evaluating the proposal, much depends on how the funds are actually spent. Many items on an agenda such as those laid out by Najman and d'Orville (1995) and Mendez (1995b), if they could be carried out with a reasonable level of international consensus and

were to disappear, and minor currencies were exchanged directly, then the number of transactions would fall by almost another factor of two.

${ }^{33}$ If the transaction-to-customer ratio fell only modestly, from three to 2 (instead of falling to one half), volume would be $\$ 602$ billion/day, and yearly revenue $\$ 1.445$ trillion $[=.01 * 240 * 602]$. 
administrative efficiency, strike an outsider as among the most useful contributions to world welfare that the public sector could make. Concerns arise over whether such international undertakings can in fact be carried out this effectively.

Much of current public opinion in many countries, particularly the United States, is opposed even to current levels of international cooperation, let alone to the massive increases in spending and activity envisioned in such an agenda. To assert that the level of political consensus currently exists is wishful thinking. ${ }^{34} \quad$ Popular conceptions are of large donothing bureaucracies, where the major function is to provide sinecures for favored nationals of the member countries. (The old UNESCO comes to mind.) Much of the harsh opinion is based on ignorance, ranging from the mild to the extreme. ${ }^{35}$

One can take some encouragement from some public opinion polls that have been recently conducted with care by Kull (1995) of the Center for the Study of Policy Attitudes. They find higher numbers of Americans prepared to allocate resources to worthy international causes than is generally assumed. It would probably be necessary for countries to be able to agree on reformed institutional mechanisms to insure that the money was wellspent (such as agreeing to choose staff based more on merit and less on national quotas). It

\footnotetext{
${ }^{34}$ Walker (1993) takes encouragement from the fact that the EU (European Union) is already collecting taxes across its members: "The principal of supranational taxes for supranational purposes has been established." But it is a very long way from claiming sufficient political consensus in the EU for federal public finance to any possible claim that such an international consensus exists more broadly.

${ }^{35}$ Typical of the mild ignorance is the tendency to blame U.N. military inaction in the face of crises on the institution itself, instead of on the failure of its most important members to agree on the proper course of action (and to contribute their share of the costs!). Typical of the more extreme ignorance is the belief that the U.N. possesses armed forces of its own, and even that these may have at times operated inside the United States.
} 
would probably also be necessary to start out on a smaller scale than the list of projects, many of them at $\$ 10-\$ 100$ billion each and higher, that have been proposed. Relatively more modest projects such as disaster relief, Peacekeeping Operations, and nuclear safety related to the former Soviet Union strike the author as highest priority. Using a new tax to fund successful activities of this sort might gradually earn increased public support for U.N. activities. This is less likely to happen if idealists push for immediate massive funding of initiatives that many people do not yet see the need for at an international level. These, at least, are the reactions of one who is not an expert in this area. ${ }^{36}$

\section{c. Alternative ways of raising tax revenue}

Perhaps the most effective argument against those concerned with the distortions that a Tobin tax would create is to ask what alternative method of raising $\$ 166$ billion exists that would be less distortionary. Such mainstays of public finance as taxing incomes or international trade are probably far more distortionary. It is difficult to see, for example, what damage a Tobin tax could do to the foreign exchange market that would be commensurate to the damage to international trade from tariffs that raised the same amount of revenue.

\footnotetext{
${ }^{36}$ We saw in the revenue estimates that a tax on the order of 1 per cent raises somewhat more revenue than a tax on the order of 0.1 per cent, notwithstanding the large decline in trading volume that is likely. A proposal prhased so as to raise hundreds of billions of dollars of revenue is unlikely to be adopted, however. In this light, a strategy of backing a more modest proposal for a tax of 0.1 per cent may actually carry a higher expected revenue payoff that would a strategy of backing a tax of 1.0 per cent.
} 


\section{What is the Case Against a Tobin Tax?}

The arguments against the Tobin tax fall into two categories, distortions of economic activity, and difficulties of enforceability. They are addressed by some other papers in this conference volume. If they were not at least mentioned here, however, the paper would be incomplete, and perhaps misleading.

\section{Distortions and Inefficiencies}

\section{a. Foreign exchange market}

Any tax tends to distort the economic activities on which it falls. Those who call a tax of 1 or 2 per cent "modest," and expect no shifts in private sector behavior as a result, are engaging in wishful thinking. Given the razor-thin margins in modern financial markets, a transaction cost of 1 per cent, or even substantially less, can have major effects on the location, nature, and volume of trading. Fortunately, as we have demonstrated, the effect of a 0.1 per cent tax on investments with moderately long-term horizons is indeed small, while the effect on very short-term transactions would be large.

\section{b. Liquidity}

Even if one accepts the logic that a small $0.1 \%$ tax would be a material disincentive only to short-term transactions, and that these are the only ones that one wishes to discourage, there are still other ways that the allocation of resources could be distorted. The 
loss of liquidity might lead to larger spreads to customers. Investors who hold assets like U.S. Treasury securities, even with long-term horizons, do so in part because of their liquidity: the market in Treasury securities is sufficiently liquid that investors can count on being able to sell quickly when the time comes, and on getting close to "the" market price. If the volume of foreign exchange trading were to fall substantially in response to a Tobin tax, the reduced liquidity could impair cross-border investments at every horizon. This problem is more likely to be serious for small thinly-traded currencies.

\section{c. Market structure}

As noted when discussing the possible effects on trading volume to estimate revenue, there is the potential for a Tobin tax to change the structure of the market in a fundamental way. This issue has hardly been addressed in the debate on the Tobin tax.

There is no obvious reason why foreign exchange markets should be organized as decentralized dealer-driven markets, while many markets in equities and commodities are centralized and customer-driven. If anything, there may be a presumption that decentralized markets are more suited to assets with lower volume trading and more asymmetric information; this would explain the tendency for small stocks to list on the NASDAQ, which is an over-the-counter market, and larger stocks to list on the centralized NYSE. ${ }^{37}$ Major currencies would seem to resemble large stocks more than small ones.

${ }^{37}$ There is a sizeable literature on such microstructure questions exists for equity markets (including for example, the theoretical contributions of Madhavan, 1992, and Glosten, 1994]. Unfortunately, the conclusions to emerge from this literature are not yet clear. Moreover, the corresponding microstructure literature for the case of foreign exchange markets has barely gotten started. 
As we have seen, there is a trend toward automated systems for trading foreign exchange, particularly within the class of brokered transactions. So far, customers are completely excluded from participating. Let us, however, engage in a bit of "finance fantasy" (as in "science fantasy"). It is possible that at some point in the future, one of the automated brokerage systems would allow customers to participate. (Currently the systems are too dependent on dealers for business, to offend them by breaking the no-customer rule.) If so, a centralized customer-driven market could expand at the expense of the decentralized dealer-driven market. It is conceivable that a 1 per cent Tobin tax would accelerate this trend, because the number of transactions per customer order is much greater under the current system. The provision of liquidity by customers, e.g., through limit order books, would substitute for the current inter-dealer mechanism of risk-sharing.

Such a change in market structure would be momentous. It is not guaranteed that the change would be for the worse. It is difficult to say whether the new system would be more efficient than the current one. If the switch were to happen on its own, the presumption would be that the centralized system was more efficient. On the other hand, it is surely significant that all foreign exchange markets around the world have apparently evolved as decentralized systems, and that none has made the jump to a centralized system. If the switch were to occur as the result of a substantial Tobin tax, it would be hard to know ex ante whether the switch would lead to a gain or loss in efficiency. Ex post, one might judge by seeing whether the transactions costs to customers went up or down. This author, personally, is not brave enough to want to tamper with Mother Nature in this way. Mendez $(1994,1995 \mathrm{ab})$ is confident of the superior efficiency of a centralized 
electronic system to match customers buy and sell orders, considers it a natural monopoly, and proposes that the United Nations or other international organizations should set one up. He asserts that costs to customers would go down. He is so confident of the efficiency gains that he believes that huge sums of revenue could be raised, in the manner of the Tobin tax, apparently without even attempting to ban legally untaxed foreign exchange trading of the conventional sort. The question that has not been answered satisfactorily is why, if the centralized system would be so efficient and profitable, someone hasn't already started one somewhere.

\section{Enforceability}

Enforceability is a big problem for the Tobin tax. The issue is considered at length by Garber (1995) and Kenen (1995), and so shall be considered only very briefly here. ${ }^{38}$

\section{a. In individual countries}

If any of the proponents of a Tobin tax once thought that it could be enacted in the United States alone, they have probably been convinced otherwise by now. It is clear that the response, even to a tax as small 0.1 per cent, would be for the foreign exchange markets to move elsewhere. In this regard, it is worth noting that the magnitude of dollar/DM trading in London already exceeds the amount traded in New York ( $\$ 102$ billion/day vs. $\$ 73$

${ }^{38}$ Most studies of financial transactions taxes in general, such as Campbell and Froot (1995), Hakkio (1994), Schwert and Seguin (1993), and Shome and Stotsky (1995), conclude that enforcement is a serious problem, even in the domestic context. Some, notably Summers (1987) and Summers and Summers (1990), are much more optimistic. 
billion, according to the latest surveys). The same applies if the tax were applied to a set of the largest markets. If the tax were limited to the G-7, the markets would move to Singapore and Luxembourg. If it were limited to the OECD plus Hong Kong and Singapore, the markets would move to the Cayman Islands and the Isle of Man.

For the policy to achieve any of its goals, it would have to be the outcome of an international agreement that was virtually universal. (It could withstand a few "outlaw" states like North Korea and Iraq not joining, since they are already so cut off from international financial business.) Getting international agreement for such a tax is the greatest practical difficulty to its enactment. It is not the place of academic observers to prejudge political practicality, however; if we don't try to judge innovative new proposals on their merits, nobody will.

\section{b. By international agreement}

Enforcement could still be a problem, even if all countries were to sign an agreement. As it is, foreign exchange is already traded on street corners in over half the countries of the world, in markets that are various shades of gray and black. For small tax rates and large transactions, street corners are less of a problem.

Some have suggested that the automated systems that are growing in use, in brokering as well as in direct inter-dealer trading, could make collection easier. If problem number one could be solved (the international agreement), a big "if," there is no reason to think that enforcement would be difficult for financial transaction taxes as compared to, say, income taxes. 


\section{Conclusion}

The author is by no means ready to endorse the Tobin tax, especially one on the order of 1 or 2 per cent. Doubts over enforceability, even by themselves, are too great. Some proponents of the tax have not thought through carefully enough the implications for the magnitude, location, and microstructure of the foreign exchange market. ${ }^{39}$

Proponents should realize that most economists would oppose such a tax. Their opposition cannot be dismissed quite as easily as the self-interested opposition of the banks, even though the language will often sound similar. The economists' basic points must be acknowledged: (1) there is a presumption that decisions made collectively by the private sector in competitive markets, such as where to set the market price for foreign exchange or even how to organize the market itself, have good reasons behind them, (2) economic behavior responds endogenously to taxes, and (3) there is no reason to think that the public sector will necessarily spend resources more efficiently than the private sector.

On the other hand, economists are wrong to be content at stopping at such reflexive reactions as these alone. The arguments on the pro side are easily summed up. (1) There is evidence that the foreign exchange markets do not currently operate in quite the optimal way that the theoretical ideal would have us believe. (2) Contrary to standard claims, there is at least some reason to believe that a Tobin tax might impact destabilizing short-term speculation more than stabilizing long-term speculation. (3) Subject to the hugely important condition of worldwide enforcement, the Tobin tax could raise a lot of money. (4) Subject

${ }^{39}$ Though other proponents have thought these issues through carefully. 
to the equally important condition that the public finance was handled more responsibly than is often the case in national politics, let alone international politics, worthwhile projects could be financed at the cost of substantially lower economic distortions than would be the case with (for example) tariffs. The difficulty of meeting these two conditions is the primary reason why I am not yet ready to sign on. Nevertheless the proposal is worthy of more serious study than economists have hitherto given it. 


\section{Daily Turnover in the U.S. Foreign Exchange Market}

$\$$ billion/day

Market Totals of which Brokers

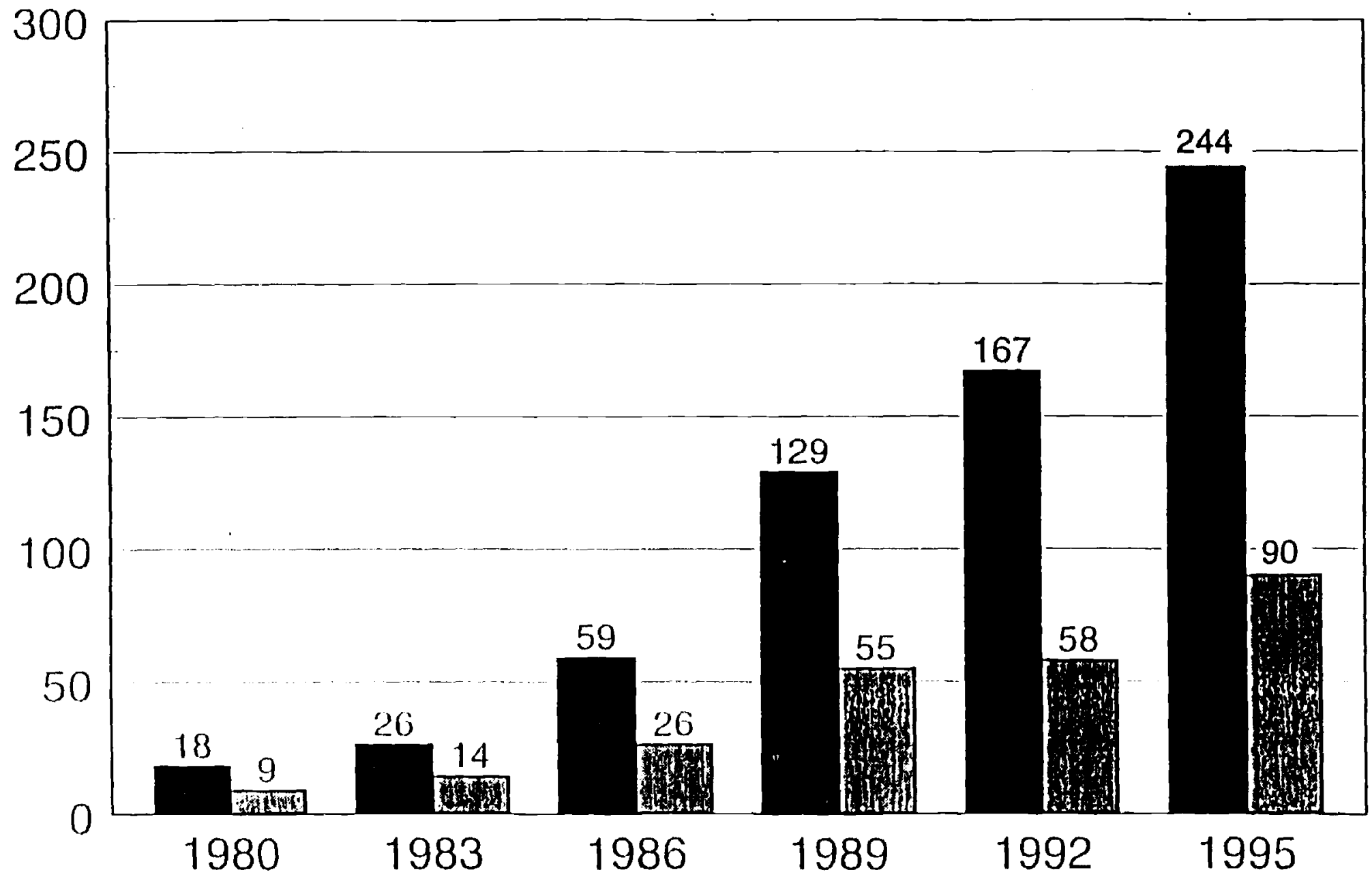




\section{Trading Methods \\ Percentage of Total Market Volume}

1992

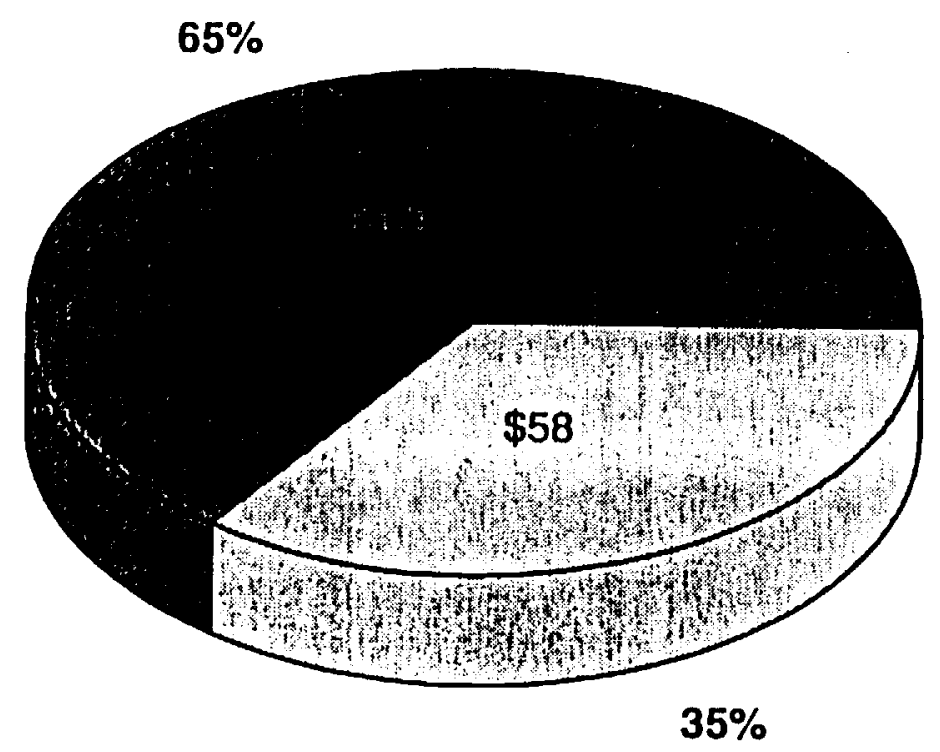

Source: Federal Reserve Bank of New York
1995

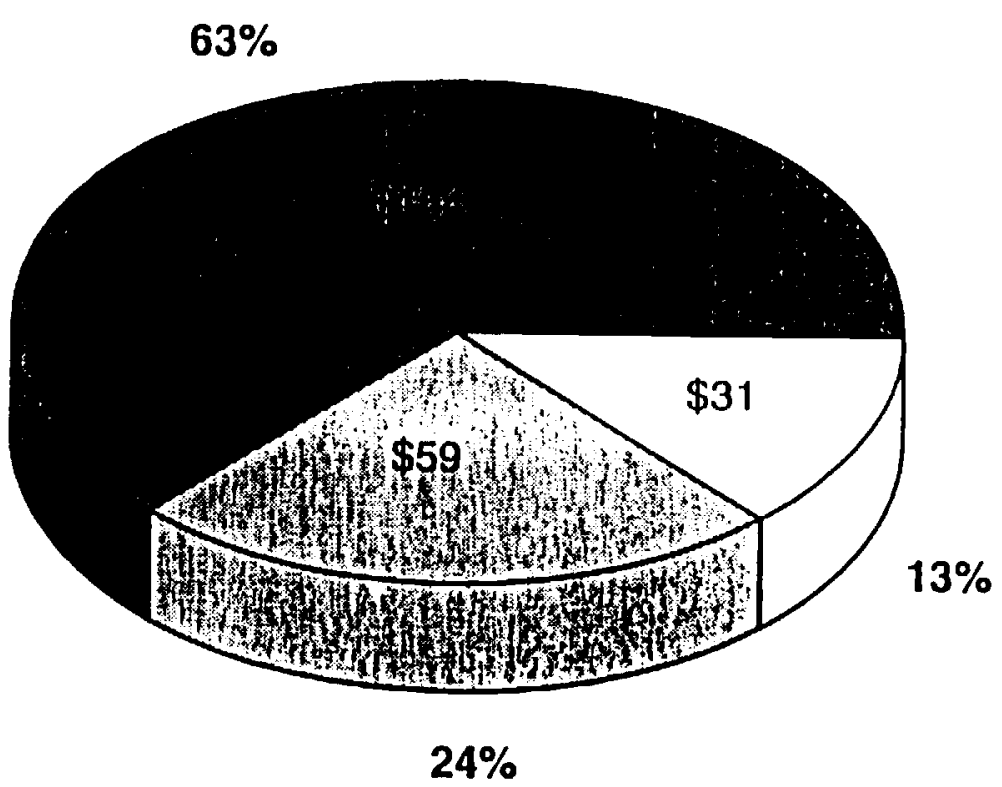

\section{Legend}

Direct

Voice Brokers

Automated Brokers 


\section{2, 1995 Comparison of Foreign Exchange Daily Turnover}

a. Percentage Share by Currency Pair

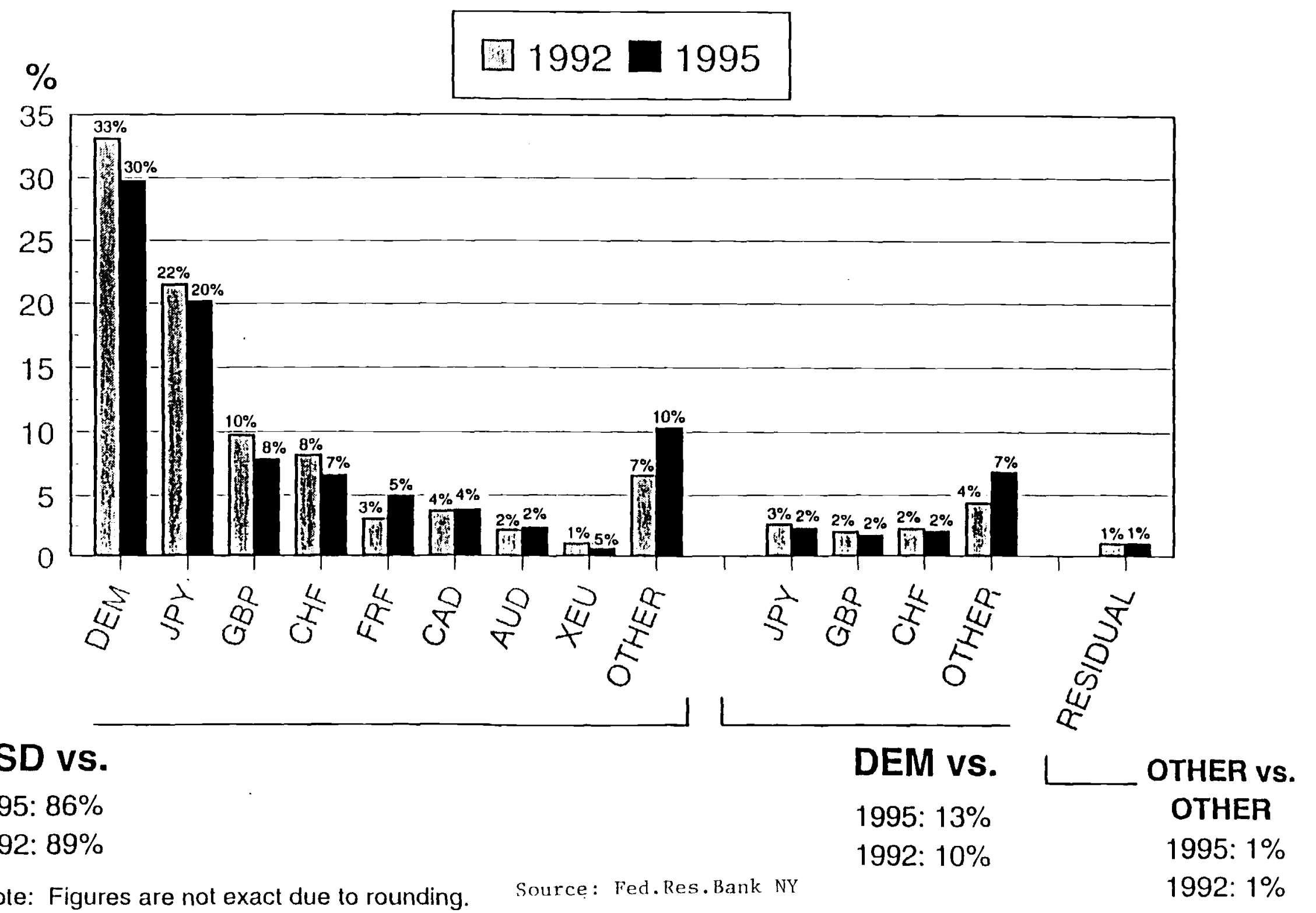




\section{Counterparty Distribution}

( $\$$ billion/day)

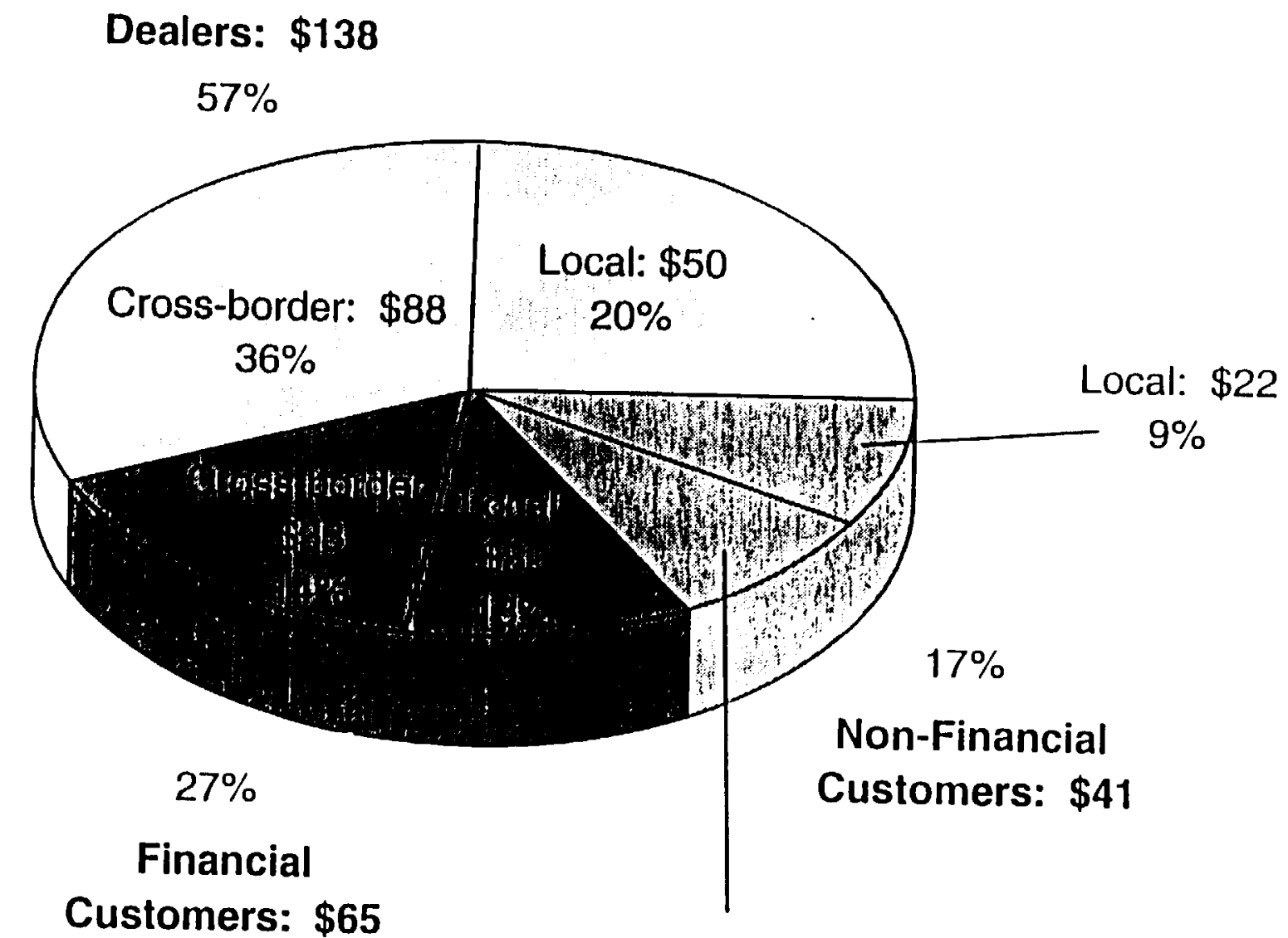

Cross-border: $\$ 19$

$8 \%$ 
(a) Changes in the Nomirat Marki Dollat Rate

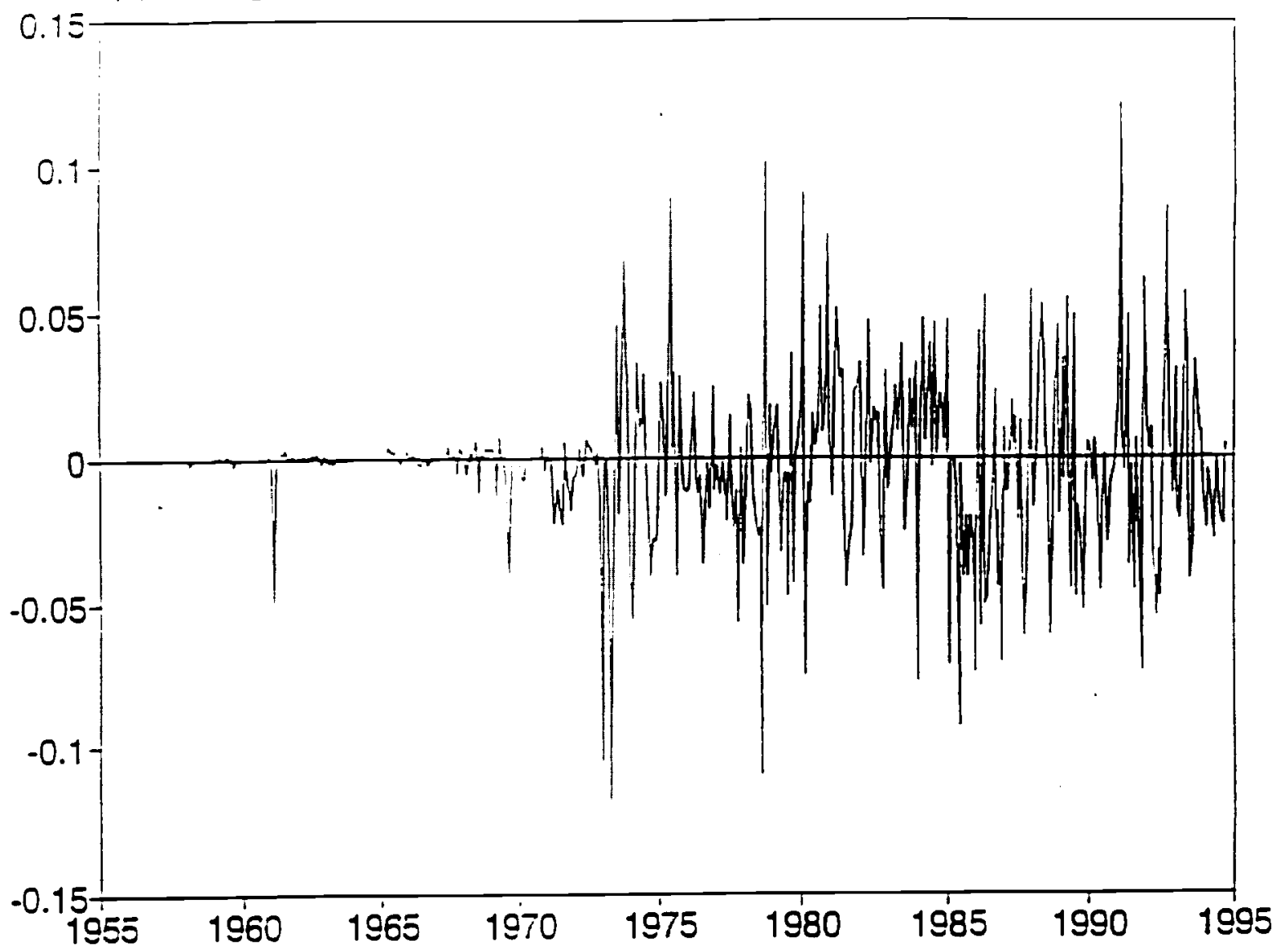

(b) Changes in the Real Mark/Dollar Rate

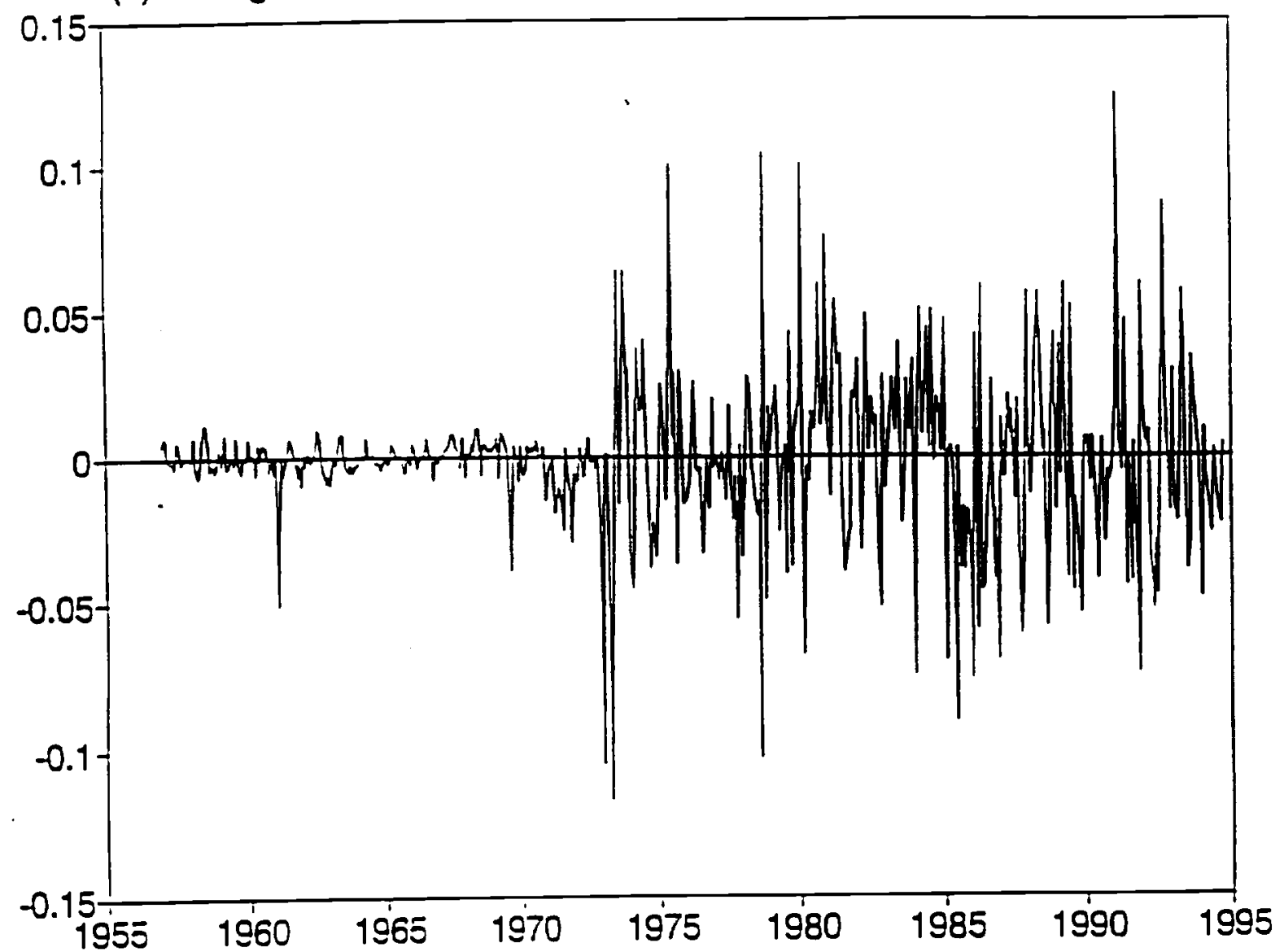

Figure 5: The suitch Eran Eived-rata rezi-e to floating raises raal exchange rate volatilit 
Table 1: Three proposals for "sand in the wheels" capital controls, and how they differ

\begin{tabular}{|c|c|c|c|}
\hline & $\begin{array}{l}\text { Chile's deposit } \\
\text { requirement on } \\
\text { inflows }\end{array}$ & $\begin{array}{l}\text { Eichengreen-Wyplosz } \\
\text { deposit requirement } \\
\text { proposal }\end{array}$ & Tobin tax proposal \\
\hline 1. Motive & $\begin{array}{l}\text { Prevent over- } \\
\text { indebtedness }\end{array}$ & $\begin{array}{l}\text { Protect balance of } \\
\text { payments }\end{array}$ & $\begin{array}{l}\text { Reduce volatility in } \\
\text { exchange rate (and } \\
\text { raise revenue) }\end{array}$ \\
\hline 2. Tax applied to: & Capital inflows & $\begin{array}{l}\text { Capital outflows } \\
\text { (and inflows) }\end{array}$ & $\begin{array}{l}\text { All foreign exchange } \\
\text { transactions, } \\
\text { including trade }\end{array}$ \\
\hline $\begin{array}{l}\text { 3. Paid immediately } \\
\text { by: }\end{array}$ & Foreign investors & Banks & $\begin{array}{l}\text { All traders } \\
\text { (mostly banks) }\end{array}$ \\
\hline $\begin{array}{l}\text { 4. Paid immediately } \\
\text { to: }\end{array}$ & $\begin{array}{l}\text { Central bank (foreign } \\
\text { currency earnings) }\end{array}$ & $\begin{array}{l}\text { Central bank } \\
\text { (seignorage only) }\end{array}$ & $\begin{array}{l}\text { Tax authority } \\
\text { (domestic revenue) }\end{array}$ \\
\hline $\begin{array}{l}\text { 5. Relationship of } \\
\text { tax amount to } \\
\text { interest rate }\end{array}$ & $\begin{array}{l}\text { Rises with foreign } \\
\text { interest rate }\end{array}$ & $\begin{array}{l}\text { Rises with domestic } \\
\text { interest rate }\end{array}$ & $\begin{array}{l}\text { Invariant to interest } \\
\text { rate }\end{array}$ \\
\hline $\begin{array}{l}\text { 6. Relationship to } \\
\text { maturity }\end{array}$ & $\begin{array}{l}\text { Tax falls at } 3 \text { mos. } \\
\text { (or } 12 \text { mos.) }\end{array}$ & $\begin{array}{l}\text { Falls with maturity? } \\
\text { But does not apply to } \\
\text { intra-day trading }\end{array}$ & $\begin{array}{l}\text { Fixed amount. } \\
\text { In \% p.a. terms, } \\
\text { falls continuously } \\
\text { with maturity. }\end{array}$ \\
\hline 7. Where imposed & $\begin{array}{l}\text { One country } \\
\text { (facing inflows) }\end{array}$ & $\begin{array}{l}\text { One country } \\
\text { (facing outflows) }\end{array}$ & Must be world-wide \\
\hline $\begin{array}{l}\text { 8. Probable level of } \\
\text { tax rate }\end{array}$ & Moderate & $\begin{array}{l}\text { High (to discourage } \\
\text { speculative attacks) }\end{array}$ & $\begin{array}{l}\text { Low (to avoid } \\
\text { distortions and } \\
\text { substitution) }\end{array}$ \\
\hline
\end{tabular}


Table 2

Do forecasters extrapolate? OLS regressions of expected future rate of depreciation against most recent actual depreciation

\begin{tabular}{lccccc}
\hline Survey data source & \multicolumn{2}{l}{ MMS International } & \multicolumn{3}{l}{ Economist Financial Report } \\
\hline Sample period & \multicolumn{2}{l}{ Oct. 1984-Jan. 1988 } & \multicolumn{2}{l}{ June 1981-Aug. 1988 } \\
Term of forecast & 1-week & 4-week & 3-month & 6-month & 12-month \\
Estimate of extrapolative & & & & & \\
parameter & .13 & .08 & -.08 & -.17 & -.33 \\
Standard error (GMM) & .03 & .05 & .03 & .03 & .06 \\
t-statistic & $4.32^{*}$ & 1.60 & $-2.98^{*}$ & $-4.98^{*}$ & $-5.59^{*}$ \\
\hline
\end{tabular}

- Significant at 99 percent confidence level.

Source: Frankel and Froot (1990) 


\begin{tabular}{|c|c|c|c|}
\hline Countr: & $\begin{array}{l}\text { Tax Size } \\
\text { 1991 }\end{array}$ & Description & . Cuves: Changes since 1991 \\
\hline Australia & $0.3 r_{t}$ & Trancacion iax & Acillunal stame lor removed in 1991 \\
\hline \multirow[t]{3}{*}{ Austrin } & $0.15 \%$ & Trimeicer tiax & 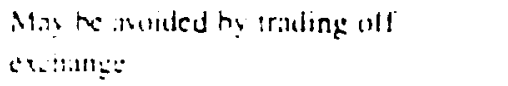 \\
\hline & $0.06 \%$ & Arrangement fee & $\begin{array}{l}\text { May be aroided by uading off } \\
\text { eximange }\end{array}$ \\
\hline & $0.04 \tau-0.09 \%$ & Courage fee & \\
\hline \multirow[t]{2}{*}{ Beigium } & $0.17 r_{\mathrm{c}}$ & Stamp tax on buys and sells & $\begin{array}{l}\text { No:2x ex countr: maximum of } \\
10.000 \text { E eigian francs }\end{array}$ \\
\hline & 0.0255 & Stock marker fee & $\begin{array}{l}\text { No :ar ex couner: maximum of } 2.500 \\
\text { Beisian irancs }\end{array}$ \\
\hline Canada & & No taxes & \\
\hline Denmark & & No taxes for nonresidents & \\
\hline Finland & $0.5 \tau_{c}$ & Transaction tax & $\begin{array}{l}\text { Waived if both fartes foreign. } \\
\text { eiiminated in 199? }\end{array}$ \\
\hline France & $0.15 \tau$ & Trading Lax & $\begin{array}{l}\text { Tax on trades }>1 \text { milliun francs, rate } \\
\text { is doubled on smaller transactions. } \\
\text { may te aroided by uading ex country }\end{array}$ \\
\hline \multirow[t]{2}{*}{ Germany } & $0.125 \%$ & Boersmumsatz Stever & Resicients only \\
\hline & $0.06 \tilde{r}_{\mathfrak{r}}$ & $\begin{array}{l}\text { Courage tax (official broker } \\
\text { fee) }\end{array}$ & $\begin{array}{l}\text { Tax may be avoided by trading ex } \\
\text { courisy }\end{array}$ \\
\hline \multirow[t]{3}{*}{ Hung Kong } & $0.25 \%$ & Stamp duty & \\
\hline & $0.006 \%$ & Special levy & May the avided by trading off market \\
\hline & $0.050 \%$ & Exchange levy & May be aroided hy trading off market \\
\hline Italy & $0.05 \%$ & Stamp duty tax & $\begin{array}{l}\text { Tar may be avoided by trading ex } \\
\text { country }\end{array}$ \\
\hline Japan & $0.30 \%$ & Sales tax & May be arnided by trading ex country \\
\hline \multirow[t]{2}{*}{ Malaysia } & $0.05 \%$ & Clearing fee & $\begin{array}{l}\text { Naximum } \$ 100 \text { : may be avoided by } \\
\text { traing off exchang: }\end{array}$ \\
\hline & $0.3 \%$ & $\begin{array}{l}\text { Transfer stamp duty on } \\
\text { purchases and sales }\end{array}$ & Eliminated in 1992 \\
\hline Necheriands & & No laxes & \\
\hline New Zealand & $\begin{array}{l}0.0057 \% \text { plus } \\
\text { per vade fee }\end{array}$ & Transaction levy & $\begin{array}{l}\text { May be aroided by trading off } \\
\text { exchange: etiminated in } 1992\end{array}$ \\
\hline Norway & & No taxes & \\
\hline \multirow[t]{3}{*}{ Singapore } & $0.1 \%$ & Contract stamp duty & $\begin{array}{l}\text { Nay be avoided by trading off } \\
\text { exchange }\end{array}$ \\
\hline & $0.05 t$ & Clearing fee & $\begin{array}{l}\text { Maximum } 5 \$ 100 \text {. may be avoided by } \\
\text { uading oil exchange }\end{array}$ \\
\hline & $0.2 q$ & Transfer stamp duty & Purchases only: eliminated in 1992 \\
\hline Sweden & $0.5 \%$ & Tumover tas & $\begin{array}{l}\text { Tax may be avoided by trading ex } \\
\text { counury: eliminated in } 1991\end{array}$ \\
\hline \multirow[t]{3}{*}{ Swilzerlond } & $0.0005 \%$ & Exchange fee & $\begin{array}{l}\text { Tax may be avoided by uading ex } \\
\text { country }\end{array}$ \\
\hline & $0.01 \%$ & State tax & $\begin{array}{l}\text { Tax may be avoided by trading ex } \\
\text { country }\end{array}$ \\
\hline & $0.075 \%$ & Stamp tax & $\begin{array}{l}\text { Tax may be avoided by uading ex } \\
\text { country }\end{array}$ \\
\hline United States & 0.00335 & SEC fee & \\
\hline \multirow[t]{2}{*}{ United Kingdom } & 2 pounds & Levy & On trades over $\mathbf{E . 0 0 0}$ \\
\hline & $0.5 \%$ & Stamp duly lax & On purchases only \\
\hline
\end{tabular}

Source: UBS Phillips and Drew. as reported by Campbel1 and Froot (1994) 


\section{Appendix:}

\section{A Model in which a Reduction in Short-Term Speculation is Stabilizing}

Assume that the spot exchange rate, $s$ in log form, is determined by the ratio of the supply of domestic assets (relative to foreign assets), $m$ in $\log$ form, to the relative demand for domestic assets, $d$ in log form:

$$
s=m-d+u,
$$

where $u$ is an unknown error term. Assume that a fraction $w$ of participants ${ }^{40}$ in the foreign exchange market are long-term investors and a fraction 1-w are short-term speculators:

$$
d=w d_{i}+(l-w) d_{s}
$$

Assume that the investors expect the exchange rate to regress toward its long-run equilibrium value, as in the Dornbusch overshooting model, at rate $\theta$, and that the speculators expect it to diverge, as along a speculative bubble path, at rate $\delta$ :

$$
\begin{aligned}
& \exp d e p r_{i}=-\theta(s-\bar{s}) \\
& \exp d e p r_{s}=+\delta(s-\bar{s}) .
\end{aligned}
$$

Assume further that $f_{i}$ and $f_{s}$ represent the elasticity of each group's demand for foreign assets with respect to their expectations. The $f$ parameters can be interpreted as the degree of international capital mobility, or substitutability. Then total demand for domestic assets is given by:

$$
d=w f_{i} \theta(s-\bar{s})-(1-w) f_{s} \delta(s-\bar{s})
$$

Solving for the spot rate gives:

$s=\left\{m+\left[-(1-w) f_{s} \delta+(w) f_{i} \theta\right] \bar{s}+u\right\} /\left\{1-(1-w) f_{s} \delta+(w) f_{i} \theta\right\}$.

Thus the variability of the spot rate is given by:

$\operatorname{Var}(s)=\operatorname{Var}(m+u) /\left[1+w f_{i} \theta-(1-w) f_{s} \delta\right]^{2}$.

${ }^{40}$ To be more precise, we should define $d$ to be the fraction of world wealth allocated to domestic assets, and define $w$ and $l-w$ to be the shares of wealth held by the two classes of market participants. Then $s$ would be given by $m-\log [d /(1-d)]+u$. 
For a given variance of money supplies $(m)$ and other determinants $(u)$, the investors (i) act to reduce the variance of the exchange rate, and the speculators $(s)$ to increase it. The position of McKinnon (1976) could be interpreted as worrying that volatility is too high because $f_{i}$, the responsiveness of investors to their expectations, is too low, and Tobin the position that volatility is too high because $f_{s}$, the responsiveness of speculators to their expectations is too high. The overall argument could also be stated more simply: high volatility stems from a low $w$, the number of investors relative to speculators. This fits in with concerns of some observers about excessively short horizons in financial markets. A Tobin tax could be expected to lower $f_{s}$ or to raise $w$. Either way, by decreasing the role of destabilizing speculation, it would in this model result in a lower variance of the exchange rate. 


\section{References}

Bank of England. 1986. "The market in foreign exchange in London," Press notice (August).

Bank of England. 1992. "The foreign exchange market in London," Bank of England Quarterly Bulletin 32, no.4, Nov.: 408-417.

Bank of England. 1995. "The foreign exchange market in London," Press notice, Sept. 19.

Bank for International Settlements, 1990, "Survey of Foreign Exchange Activity", Monetary and Economic Department, Basle, February.

Bank for International Settlements, 1993, "Survey of Foreign Exchange Activity in April 1992", Monetary and Economic Department, Basle, March.

Bank for International Settlements, 1995, "Central Bank Survey of Foreign Exchange Market Activity in April 1995: Preliminary Global Findings," Basel, 24 October.

Bank of Japan, 1995, "Tokyo Foreign Exchange Market Turnover Survey (April 1995)," Tokyo, September 19.

Campbell, John, and Richard Clarida, 1987, "The dollar and real interest rates," CarnegieRochester Conference on Public Policy 27 (August).

Campbell, John, and Kenneth Froot, "Securities Transaction Taxes: Lessons from International Experience." in The Internationalization of Equity Markets, J.Frankel, ed., University of Chicago Press, Chicago, 1994.

Cutler, David, James Poterba and Lawrence Summers, 1991, "Speculative dynamics" Review of Economics Studies, 58, May, 529-546.

DeGrauwe, Paul, and Hans Dewachter, 1990, "A Chaotic Monetary Model of The Exchange Rate," Centre for Economic Policy Research Discussion Paper No. 466, Oct.

De Long, J. Bradford, Andrei Shleifer, Lawrence Summers and Robert Waldmann (1990) "Noise Trader Risk in Financial Markets" Journal of Political Economy 98-4, 703-38.

Dornbusch, Rudiger, and Jeffrey Frankel, 1988, "The Flexible Exchange Rate System: Experience and Alternatives," in International Finance and Trade, edited by S. Borner, International Economics Association, in association with Macmillan Press: London.

Eichenbaum, Martin, and Charles Evans, "Some Empirical Evidence on the Effects of Monetary Policy Shocks on Exchange Rates," NBER Working Paper No. 4271. 
Forthcoming, Quarterly Journal of Economics Nov. 1995.

Eichengreen, Barry, James Tobin and Charles Wyplosz, 1995, "Two Cases for Sand in the Wheels of International Finance," CIDER Working Paper No. C94-45; The Economic Journal 105, 162-172.

Engel, Charles, 1995, "Why Is There a Forward Discount Bias? A Survey of Recent Evidence," University of Washington and NBER, July.

Federal Reserve Bank of New York, 1983, "Foreign Exchange Transactions..." press release Sept. 7.

Federal Reserve Bank of New York, 1989, "Summary of Results of U.S. Foreign Exchange Market Survey Conducted in April 1989," press release Sept. 13.

Federal Reserve Bank of New York, 1995, "April 1995 Central Bank Survey of Foreign Exchange Market Activity," September 19.

Fieleke, Norman, 1981, "Foreign-Currency Positioning by U.S. Firms: Some New Evidence," Review of Economics and Statistics LXIII, no.1, Feb. 35-42.

Flood, Robert, and Andrew Rose, 1993, "Fixing Exchange Rates," NBER Working Paper 4503.

Frankel, Jeffrey, 1988, "International Capital Mobility and Exchange Rate Volatility," in International Payments Imbalances in the 1980's, N. Fieleke, ed., Federal Reserve Bank of Boston, Boston, Ma..

Frankel, Jeffrey, 1993, On Exchange Rates, MIT Press, Cambridge, MA.

Frankel, Jeffrey and Kenneth Froot, 1987, "Using Survey Data to Test Standard Propositions Regarding Exchange Rate Expectations," American Economic Review 77, no. 1 (March), 133-153.

Frankel, Jeffrey and Kenneth Froot, 1987a, "Short-Term and Long-Term Expectations of the Yen/Dollar Exchange Rate: Evidence from Survey Data," Journal of the Japanese and International Economies 1, 249-74.

Frankel, Jeffrey and Kenneth Froot, 1990, "Chartists, Fundamentalists, and the Demand for Dollars" in Anthony Courakis and Mark Taylor, eds., Private Behavior and Government Policy in Interdependent Economies. Oxford: Clarendon Press.

Frankel, Jeffrey and Andrew Rose, 1995, "A Survey of Empirical Research on Nominal Exchange Rates," NBER Working Paper no. 4865; for Handbook of International 
Economics, edited by G. Grossman and K. Rogoff, North-Holland, Amsterdam.

Frankel, Jeffrey and Shang-Jin Wei, 1995, "Regionalization of World Trade and Currencies: Economics and Politics," NBER conference in Woodstock, VT, October 19-21. In The Regionalization of the World Economy, J. Frankel, editor, University of Chicago Press, forthcoming.

Friedman, Milton, 1953, "The Case for Flexible Exchange Rates" in Essays in Positive Economics (University of Chicago, Chicago).

Froot, Kenneth, 1989, "Multinational Corporations, Exchange Rates, and Direct Investment, " in International Policy Coordination and Exchange Rate Fluctuations, W. Branson, J. Frenkel and M. Goldstein, eds., University of Chicago Press: Chicago, 1990.

Froot, Kenneth, and Jeffrey Frankel, 1989, "Forward Discount Bias: Is it an Exchange Risk Premium?" Quarterly Journal of Economics 104, no.1 (February), 139-161.

Froot, Kenneth A. and Takatoshi Ito, 1989, "On the Consistency of Short-Run and Long-Run Exchange Rate Expectations" Journal of International Money and Finance 8, no. 4, 487-510.

Garber, Peter, 1995, "Issues of Enforcement and Evasion in a Levy on Foreign Exchange Transactions," conference on New and Innovative Sources of Financing Development, United Nations Development Programme, New York, October.

Glosten, Lawrence, 1994, "Is the Electronic Open Limit Order Book Inevitable? Journal of Finance 49, no.4, Sept., 1127-.

Goldberg, Michael, and Roman Frydman, 1993, "Theories Consistent Expectations and Exchange Rate Dynamics, " forthcoming in H.Frisch and A. Worgoter, eds., Open-Economy Macroeconomics (London: MacMillan Publishing).

Goldstein, Morris, 1995, "The Exchange Rate System and the IMF: A Modest Agenda," Policy Analyses in International Economics No. 39, Institute for International Economics, Washington, D.C., June.

Goldstein, Morris, and David Folkerts-Landau, 1993, International Capital Markets, International Monetary Fund, Washington, D.C.

Goodhart, Charles, 1988, "The Foreign Exchange Market: A Random Walk with a Dragging Anchor" Economica 55, 437-60.

Goodhart, Charles, Takatoshi Ito, and R. Payne, "One Day in June, 1993: A Study of the Working of Reuters 2000-2 Electronic Foreign Exchange System," Bank of Italy, Perugia, Italy, July 1994. In The Microstructure of Foreign Exchange Markets, edited by J.Frankel, 
G. Galli and A. Giovannini, Forthcoming, University of Chicago Press, Chicago, 1996.

Hakkio, Craig, 1994, "Should We Throw Sand in the Gears of Financial Markets?" Economic Review, Federal Reserve Bank of Kansas City, Second Quarter: 17-30.

Hsieh, David, and Allan Kleidon, 1994, "Bid-Ask Spreads in Foreign Exchange Markets: Implications for Models of Asymmetric Information," Bank of Italy, Perugia, Italy. In The Microstructure of Foreign Exchange Markets, edited by J.Frankel, G. Galli and A. Giovannini, forthcoming, University of Chicago Press, Chicago, 1996.

Hubbard, Glenn, 1993, "Securities Transactions Taxes: Tax Design, Revenue, and Policy Considerations," Tax Notes, Nov. 22, 985-1000.

Ito, Takatoshi, 1994, "Short-Run and Long-Run Expectations of the Yen/Dollar Exchange Rate, "Journal of the Japanese and International Economies 8, no. 2, June: 119-143.

Jorion, Philippe, 1994, "Risk and Turnover in the Foreign Exchange Market," Bank of Italy, Perugia, Italy, July. In The Microstructure of Foreign Exchange Markets, J. Frankel, G. Galli and A. Giovannini, eds., University of Chicago Press, Chicago, forthcoming.

Kenen, Peter, 1995, "The Feasibility of Taxing Foreign-Exchange Transactions," conference on New and Innovative Sources of Financing Development, United Nations Development Programme, New York, October.

Krugman, Paul, and Marcus Miller, 1993, "Why Have a Target Zone?" Carnegie-Rochester Conference Series on Public Policy 38 (North-Holland), 279-314.

Kull, Steven, 1995, "Americans and Foreign Aid: A Study of American Public Attitudes," Program on International Policy Attitudes, Washington, D.C., January 23.

Lyons, Richard, 1991, "Information Intermediation in the Microstructure of the Foreign Exchange Market," NBER Working Paper No. 3889. Revised as "A Simultaneous Trade Model of the Foreign Exchange Hot Potato," April 1995.

Lyons, Richard, 1993, "Tests of Microstructural Hypotheses in the Foreign Exchange Market," NBER Working Paper No. 4471. Journal of Financial Economics 39 (Oct. 1995), 321-351.

Lyons, Richard, 1994, "Foreign Exchange Volume: Sound and Fury Signifying Nothing?" in The Microstructure of Foreign Exchange Markets, J. Frankel, G. Galli and A. Giovannini, editors, forthcoming, University of Chicago Press, Chicago, 1996.

Lyons, Richard, 1995a, "Is Profit Taking Rational? A Foreign Exchange Dealer's Response," NBER Summer Institute, July 14. 
Lyons, Richard, 1995b, "Comment on 'One Day in June, 1993: A Study of the Working of Reuters 2000-2 Electronic Foreign Exchange System'," in The Microstructure of Foreign Exchange Markets, edited by J.Frankel, G. Galli and A. Giovannini, Forthcoming, University of Chicago Press, Chicago, 1996.

Madhavan, Ananth, 1992, "Trading Mechanisms in Securities Markets," Joumal of Finance 47, 2, June, 607- .

McKinnon, Ronald, 1976, "Floating Exchange Rates 1973-74: The Emperor's New Clothes," in K. Brunner and A. Meltzer, eds., Institutional Arrangements and the Inflation Problem. Carnegie-Rochester Series on Public Policy 3: 79-114.

Meese, Richard, and Kenneth Rogoff, 1983, "Empirical Exchange Rate Models of the Seventies" Journal of International Economics 14, 3-24.

Mendez, Ruben, 1994, "Harnessing the Global Foreign Currency Market: Proposal for A Foreign Currency Exchange (FXE), New York City.

Mendez, Ruben, 1995a, "Harnessing the Global Currency Market for the Global Common Good," Choices, United Nations Development Programme, New York City.

Mendez, Ruben, 1995b, "Paying for Peace and Development," Foreign Policy, Sept.

Najman, Dragoljub, and Hans d'Orville, 1995, Towards a New Multilateralism: Funding Global Priorities, Independent Commission on Population and Quality of Life, N.Y.C., May.

Obstfeld, Maurice, 1994, "The Logic of Currency Crises," Cahiers Economiques et Monetaires, Banque de France, Paris, 189-213; abridged in Monetary and Fiscal Policy in an Integrated Europe, edited by B. Eichengreen, J. Frieden, and J. von Hagen, Springer-Verlag Press, New York and Heidelberg, 1995.

Schwert, G. William, and Paul Seguin, 1993, "Securities Transactions Taxes: An Overview of Costs, Benefits and Unresolved Questions," Financial Analysts Journal 46, Sept.-Oct., 2735 .

Shome, Parthasarathi, and Janet Stowsky, 1995, "Financial Transactions Taxes," International Monetary Fund Working Paper 95/77, August.

Summers, Lawrence, 1987, "A Few Good Taxes," The New Republic Nov.30, 1987: 14-15.

Summers, Lawrence, and Victoria Summers, 1990, "The Case for a Securities Transactions Excise Tax," Tax Notes, August 13, 879-84.

Tobin, James, 1978, "A Proposal for International Monetary Reform," Eastern Economic 
Journal, 4, 3-4, 153-59.

Tobin, James, 1992, "Tax the Speculators," Financial Times, Dec. 22.

Walker, Martin, 1993, "Paying for Peace," International Economic Insights, Institute for International Economics, Washington, DC, Sept./Oct.: 25-26.

Williamson, John, 1985, The Exchange Rate System. Policy Analyses in International Economics No. 5, Institute for International Economics, Washington, D.C. 